\title{
The long and intertwined record of humans and the Campi Flegrei volcano (Italy)
}

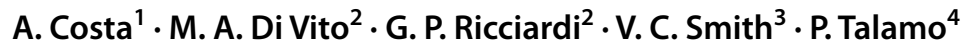

Received: 10 June 2021 / Accepted: 11 October 2021 / Published online: 10 December 2021

(c) The Author(s) 2021

\begin{abstract}
The Campi Flegrei volcano (or Phlegraean Fields), Campania, Italy, generated the largest eruption in Europe in at least $200 \mathrm{ka}$. Here we summarise the volcanic and human history of Campi Flegrei and discuss the interactions between humans and the environment within the "burning fields" from around 10,000 years until the 1538 CE Monte Nuovo eruption and more recent times. The region's incredibly rich written history documents how the landscape changed both naturally and anthropogenically, with the volcanic system fuelling these considerable natural changes. Humans have exploited the beautiful landscape, accessible resources (e.g. volcanic ash for pulvis puteolana mortar) and natural thermal springs associated with the volcano for millennia, but they have also endured the downsides of living in a volcanically active region-earthquakes, significant ground deformation and landscape altering eruptions. The pre-historic record is detailed, and various archaeological sites indicate that the region was certainly occupied in the last 10,000 years. This history has been reconstructed by identifying archaeological finds in sequences that often contain ash (tephra) layers from some of the numerous volcanic eruptions from Campi Flegrei and the other volcanoes in the region that were active at the time (Vesuvius and Ischia). These tephra layers provide both a relative and absolute chronology and allow the archaeology to be placed on a relatively precise timescale. The records testify that people have inhabited the area even when Campi Flegrei was particularly active. The archaeological sequences and outcrops of pyroclastic material preserve details about the eruption dynamics, buildings from Roman times, impressive craters that now host volcanic lakes and nature reserves, all of which make this region particularly mystic and fascinating, especially when we observe how society continues to live within the active caldera system. The volcanic activity and long record of occupation and use of volcanic resources in the region make it unique and here we outline key aspects of its geoheritage.
\end{abstract}

Keywords Archaeology $\cdot$ Campania $\cdot$ Campi Flegrei volcano $\cdot$ History $\cdot$ Human

Editorial responsibility: C.E. Gregg

This paper constitutes part of a topical collection:

Volcanic Geoheritage

A. Costa

antonio.costa@ingv.it

1 Istituto Nazionale Di Geofisica E Vulcanologia, Sezione Di

Bologna, Bologna, Italy

2 Istituto Nazionale Di Geofisica E Vulcanologia, Sezione

"Osservatorio Vesuviano", Naples, Italy

3 Research Laboratory for Archaeology and the History of Art, School of Archaeology, University of Oxford, Oxford OX1 3TG, UK

4 Parco Archeologico Dei Campi Flegrei, MiC, Pozzuoli, Italy 


\section{Sommario}

Il vulcano dei Campi Flegrei, Campania, Italia, ha generato la più grande eruzione in Europa negli ultimi $200 \mathrm{ka}$. In questo articolo riassumiamo la storia vulcanica Campi Flegrei e delle diverse comunità umane e discutiamo le interazioni tra l'uomo e l'ambiente all'interno dei "campi ardenti" da circa 10.000 anni fa, fino all'eruzione del Monte Nuovo del 1538 d.C ed ai tempi più recenti. La storia scritta ed incredibilmente ricca della regione documenta come il paesaggio si sia notevolmente modificato sia per processi naturali, prevalentemente legati all'attività vulcanica, che per l'attività dell'uomo. Gli esseri umani hanno sfruttato per millenni il bellissimo paesaggio, le risorse disponibili (ad esempio la cenere vulcanica per produrre la famosa malta con pulvis puteolana) e le sorgenti termali naturali associate al vulcanismo, ma hanno anche dovuto subire gli svantaggi di vivere in una regione vulcanica attiva con terremoti, grosse deformazioni del suolo ed eruzioni esplosive. La documentazione preistorica disponibile è molto dettagliata e vari siti archeologici testimoniano che la regione è stata sicuramente abitata negli ultimi 10.000 anni. Questa storia è stata ricostruita identificando reperti archeologici in sequenze stratigrafiche che spesso contengono strati di cenere (tefra) provenienti da alcune delle numerose eruzioni vulcaniche dei Campi Flegrei e degli altri vulcani attivi della regione (Vesuvio e Ischia). Questi strati di tefra forniscono una cronologia relativa e assoluta e consentono di collocare i ritrovamenti archeologici in una scala temporale relativamente precisa. I ritrovamenti testimoniano che le comunità umane hanno abitato l'area anche quando i Campi Flegrei erano particolarmente attivi. Le sequenze archeologiche ed i depositi piroclastici conservano dettagli sulla dinamica e impatto delle eruzioni, gli edifici di epoca romana, gli imponenti crateri che oggi ospitano laghi vulcanici e riserve naturali, tutti insieme rendono questa regione particolarmente mistica e affascinante, soprattutto quando si osserva come la società continua a vivere all'interno di un sistema calderico attivo. L'attività vulcanica e la lunga storia di occupazione e utilizzo delle risorse vulcaniche nella regione la rendono unica per gli aspetti chiave del suo geopatrimonio che qui vengono delineati.

\section{Introduction}

Around the world, people enjoy and endure living on and around active volcanoes, but perhaps nowhere is this give and take relationship better illustrated than in the Phlegraean (burning) Fields or Campi Flegrei (CF) volcano, Italy, where the volcanic and human history are intensely interwoven over tens of millennia, shaping both landscape and human activity. The Campanian volcanoes (Vesuvius, Ischia, Procida and $\mathrm{CF}$ ) (Fig. 1; note all place names referred to are marked on Fig. 1) have influenced the human population in both positive and negative ways. Here we analyse the relationship of occupation and human activity in the region, and the volcanic activity from $\mathrm{CF}$. The interspersed remnants of past cultures among the volcanic eruption deposits allow the occupations, abandonments and re-occupations of the ancient settlements and buried landscapes to be distinguished and understood.

The 79 CE eruption of Vesuvius buried Herculaneum and Pompeii in pyroclastic deposits, and these well-preserved Roman towns provide an invaluable snapshot of life at the time (Sigurdson et al., 1982, 1985). This eruption of Vesuvius was the focus of much research in the region (Macedonio et al., 1988; Barberi et al., 1990; Cioni et al., 2003; Gurioli et al., 2005) for a long time but in the 1980s researchers realised there would have been significant impact of volcanic activity from the other Campanian volcanoes and in particular CF (Rosi and Sbrana, 1987; Orsi et al., 1999; 2004; Costa et al., 2009 and references therein). Now many of the Campanian eruptions can be linked to archaeology in the region. Numerous buried soil horizons and ancient anthropized landscapes are also found in sequences on the Campanian Plain (Saccoccio et al. 2013; Di Vito et al. 2013).

The interference between archaeological contexts and volcanic deposits generates an articulated sequence, composed of volcanic, cultural and environmental data. In this sequence, the chronology of archaeological aspects obtained from closed contexts of certain date, and palaeosurfaces directly buried by the deposits of an eruption, contribute to establishing precise relative and absolute chronology. The volcanic deposits provide reliable stratigraphic markers across the region and allow the buried landscapes to be reconstructed and certain cultural aspects to be correlated with a precision that is not easily achievable outside Campania. Yet, the deposits of Vesuvius and Phlegraean eruptions have not be fully exploited in archaeology, volcanology, geomorphology and pedology studies, and integrated approaches are now starting to be used. The convergence of all these factors makes the $\mathrm{CF}$ and the Campanian Plain a perfect area for this type of research.

The record of human occupation between the eruptions of CF volcano provides an opportunity to learn about volcanic processes, the exposure to volcanic risk and the impact on society. These geologically and archaeologically rich sites provide evidence of the destruction power of nature (Migon and Pijet-Migoń 2019) and are important for geocultural heritage (Scarlett and Riede 2019). As such, these sites are attractive destinations for geotourism, and it is important that the history of these sites is clearly documented and 


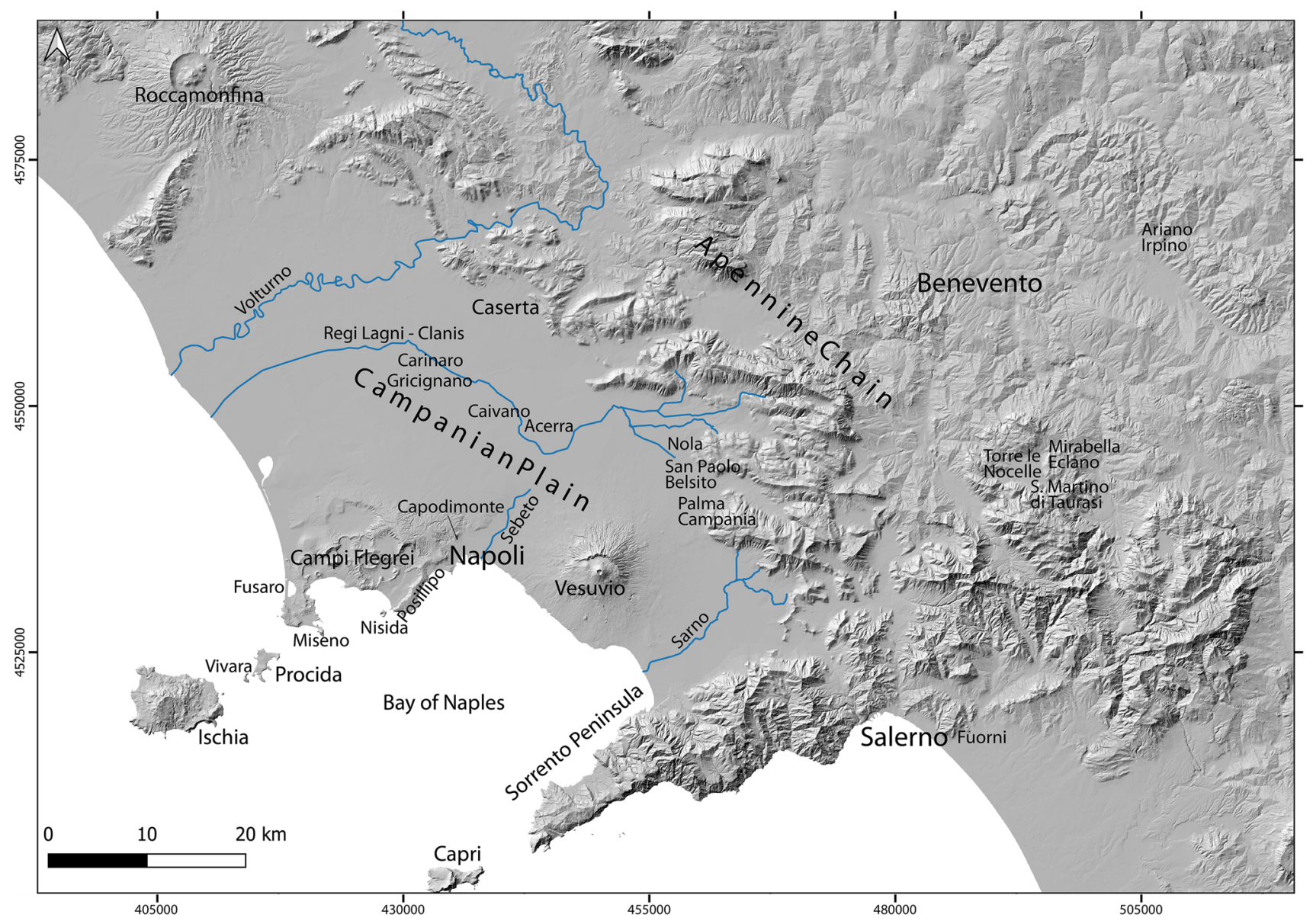

Fig. 1 Morphological map of the Campanian region, including the Campi Flegrei (CF) volcano, Vesuvio and the volcanic islands of Ischia and Procida. Other geologic features are also marked, includ- ing Roccamonfina volcano to the north and the Apennine Mountains to the east. Localities mentioned in the text are labelled

\section{Volcanic history}

\section{Campi Flegrei}

The Bay of Naples hosts a range of volcanic features that include partly submerged vents around Procida Island, the iconic Vesuvius stratocone and the resurgent caldera of Ischia. Yet the largest volcanic structure in the area is the $\mathrm{CF}$ caldera. The upper half of the $\sim 13 \mathrm{~km}$-diameter collapse structure is exposed, while the lower half is submerged beneath Pozzuoli Bay and the Tyrrhenian Sea. The caldera formed during the enormous Campanian Ignimbrite (CI) eruption that occurred at $40 \mathrm{ka}$ and covered much of South Italy and the Eastern Mediterranean region in thick volcanic ash (Barberi et al. 1978; Costa et al. 2012; Giaccio et al. 2017a, b). Another major eruption, the Neapolitan Yellow Tuff (NYT) at $15 \mathrm{ka}$, delineated the shape of the caldera (Lirer et al. 1987, Scandone et al. 1991; Fig. 1). In addition to the CI and NYT, there have been a number of other large eruptions and numerous smaller events from $\mathrm{CF}$. 
The recent eruption history of the caldera is well known but the record is less complete further back in time as the pyroclastic deposits, which provide details used to reconstruct previous activity, have been eroded and buried by the deposits of the large caldera-forming eruptions. Here we outline what has been established for the past activity of CF, starting with the most recent eruption, Monte Nuovo, for which there are written accounts from witnesses, through to what has been inferred for the oldest activity.
The Monte Nuovo eruption commenced in the evening of the 29 September $1538 \mathrm{CE}$ from a new vent in the western part of the caldera with intermittent activity spanning 6 days. This eruption occurred after a century of uplift (bradyseism) and a couple of years of frequent earthquakes, increased fumarolic activity and long-term bradyseism. The eruption ejected $\sim 0.03 \mathrm{~km}^{3}$ dense rock equivalent (DRE) of magma and built the small Monte Nuovo tuff- and scoriacone (Fig. 2). Historic observations of the eruption and its

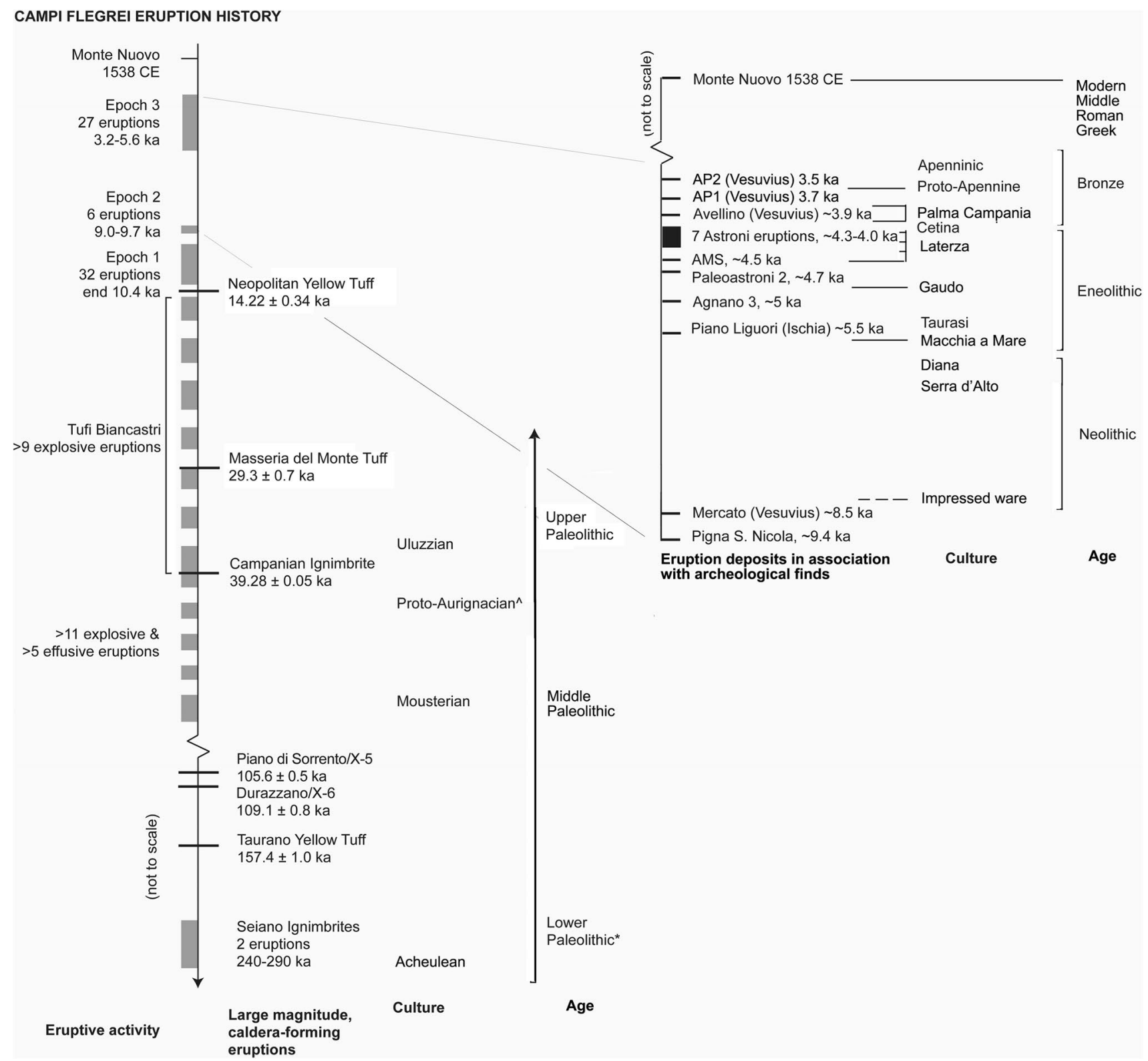

Fig. 2 The eruption history of CF and the cultural occupations (last $10 \mathrm{ka}$; right) in and around the Campanian region. Only the eruptions that are directly associated with archaeology, as explained in the text, are listed for the last $10 \mathrm{ka}$. A full list of the eruptions from $\mathrm{CF}$ in the last $14 \mathrm{ka}$ is available in Di Vito et al. (1999) and Smith et al. (2011). Vesuvius (see Di Renzo et al. 2007; Santacroce et al. 2008) and Ischia (de Vita et al. 2010) were also active in the last $10 \mathrm{ka}$. All ages are reported in cal. ka BP (see text for references), and the error bars that are provided for ages of the caldera-forming eruptions reflect the $95 \%$ probability range (2 sigma). *Lower Palaeolithic industries are associated with Neanderthals, and the ${ }^{\wedge}$ Proto-Aurignation is thought to be made by anatomically modern humans and part of the Upper Palaeolithic 
precursors are detailed below (see "The eruption of Monte Nuovo" section).

Prior to the historic Monte Nuovo eruption, there was a period of quiescence that spanned $3 \mathrm{ka}$, but before that there were more than 70 eruptions between around $14 \mathrm{ka}$ BP and 1550 BCE (3.5 ka) (Di Vito et al. 1999; Smith et al. 2011). The presence of well-developed soils and chronological evidence suggests that the eruptions occurred in 3 epochs denoted by relatively frequent eruption activity that are separated by repose periods of between 1 and $5 \mathrm{ka}$ (Rosi and Sbrana 1987; Di Vito et al. 1999). Epoch 1 extended from 14 to $10.6 \mathrm{ka}$, Epoch 2 from 9.6 to $9.1 \mathrm{ka}$ (note: all dates quoted in this paper are calibrated and presented as BP, i.e. relative to $1950 \mathrm{CE}$ ) and Epoch 3 commenced at around $5.5 \mathrm{ka}$ and ended at around $3.5 \mathrm{ka}$ (Smith et al. 2011). These epochs of frequent eruptive activity were followed by a period of quiescence that was interrupted by the eruption of Monte Nuovo at 1538 CE. The eruptions in the last 14 ka typically came from new vents at different locations within the caldera (Fig. 3). The activity ranged from Strombolian to Vulcanian with eruptions ejecting less than $0.01 \mathrm{~km}^{3} \mathrm{DRE}$ of magma, which equates to eruption magnitude (following Pyle 2000) of 3 (M3), through to M5 Plinian events that erupted $\sim 1 \mathrm{~km}^{3}$ DRE (Smith et al. 2011). The largest eruptions were the Agnano Monte Spina at $4.5 \mathrm{ka}$ and the $12 \mathrm{ka}$ Pomici Principali (Di Girolamo et al. 1984; Di Vito et al. 1999; Orsi et al. 1996) events. Both eruptions had Plinian phases and erupted around $0.85 \mathrm{~km}^{3}$ DRE (Smith et al. 2011), and their deposits are distributed across $>800 \mathrm{~km}^{2}$ of the central Campanian Plain and to the western Apennines (Orsi et al. 2004). Many of the post $15 \mathrm{ka}$ eruptions generated small cones and vents that are prominent features in the caldera, such as the Astroni and Solfatara craters, Monte Gauro and Lake Averno (see Fig. 3, Fig. 4 and Fig. 5). A few eruptions were accompanied by the extrusion of lava domes.

Prior to the relatively small and frequent eruptions in the last $14 \mathrm{ka}$, there was the large caldera-forming eruption of the NYT (Lirer and Munno 1975; Lirer et al. 1987; Scandone et al. 1991; Orsi et al. 1992). The NYT deposits can be divided into two members (Scarpati et al. 1993),

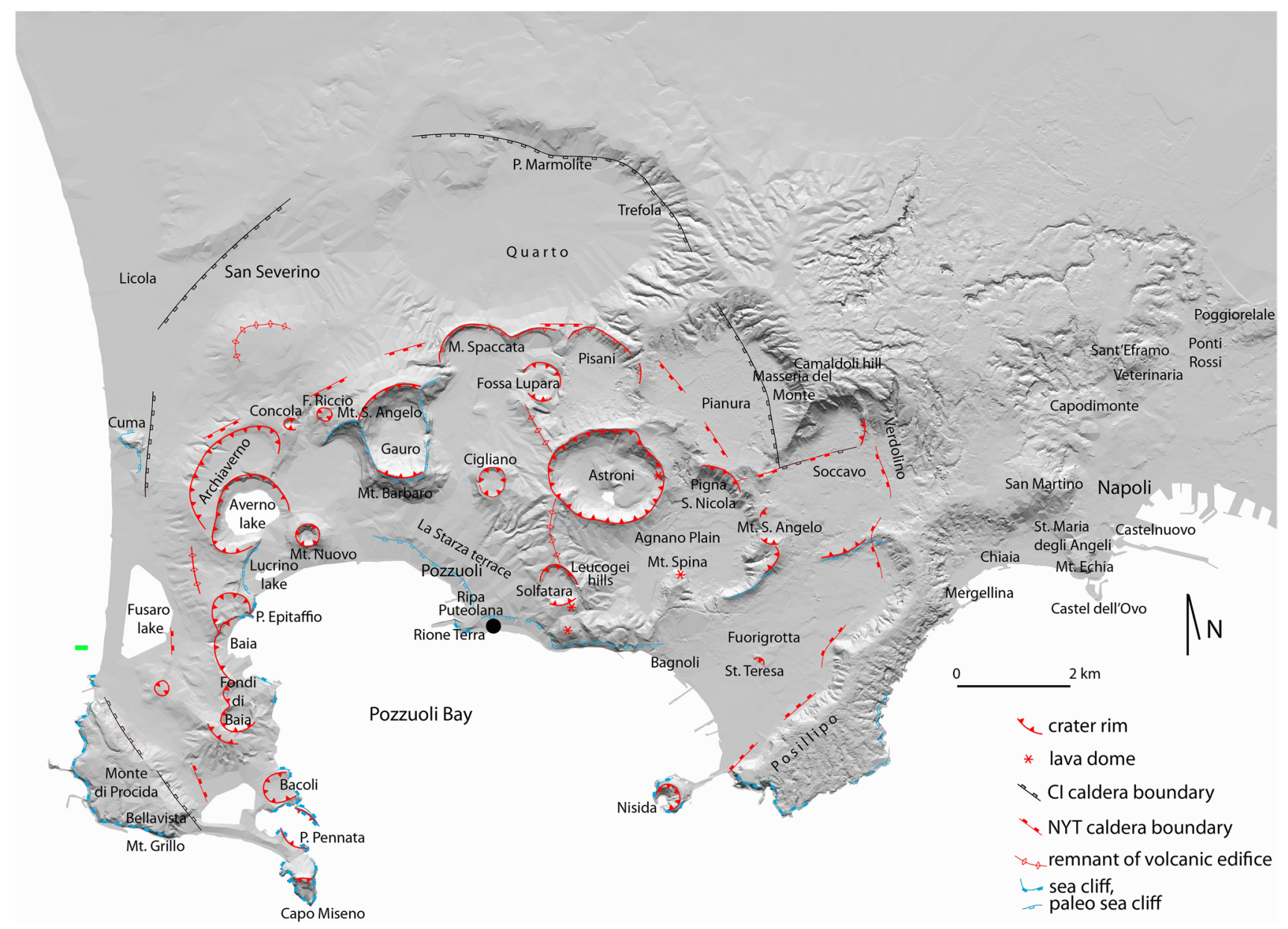

Fig. 3 Map of the CF caldera and the Campanian area. The main features and those mentioned in the text are marked, including the collapse structures that formed during the $40 \mathrm{ka}$ CI eruption (outer scarps) and the $14 \mathrm{ka}$ NYT eruption (inner scarps). Vent areas for some of the eruptions in the last $14 \mathrm{ka}$ are marked, which include the Astroni, Nisida and Gauro cones and Lake Averno. The black dot indicate the benchmark 25, reported in Fig. 8 
Fig. 4 Photographs of various features within the CF caldera. a Lake Averno and the $\mathbf{b}$ Temple of Apollo on the shores of the lake. c Bocca Grande fumarole and $\mathbf{d}$ wider area within the geothermally active Solfatara crater. e The Nisida cone on the southeastern side of the caldera. f The large Gauro cone in the NW part of the caldera, which was formed by an eruption after the NYT event. g Capo Miseno on the SW margin of the $\mathrm{CF}$ caldera

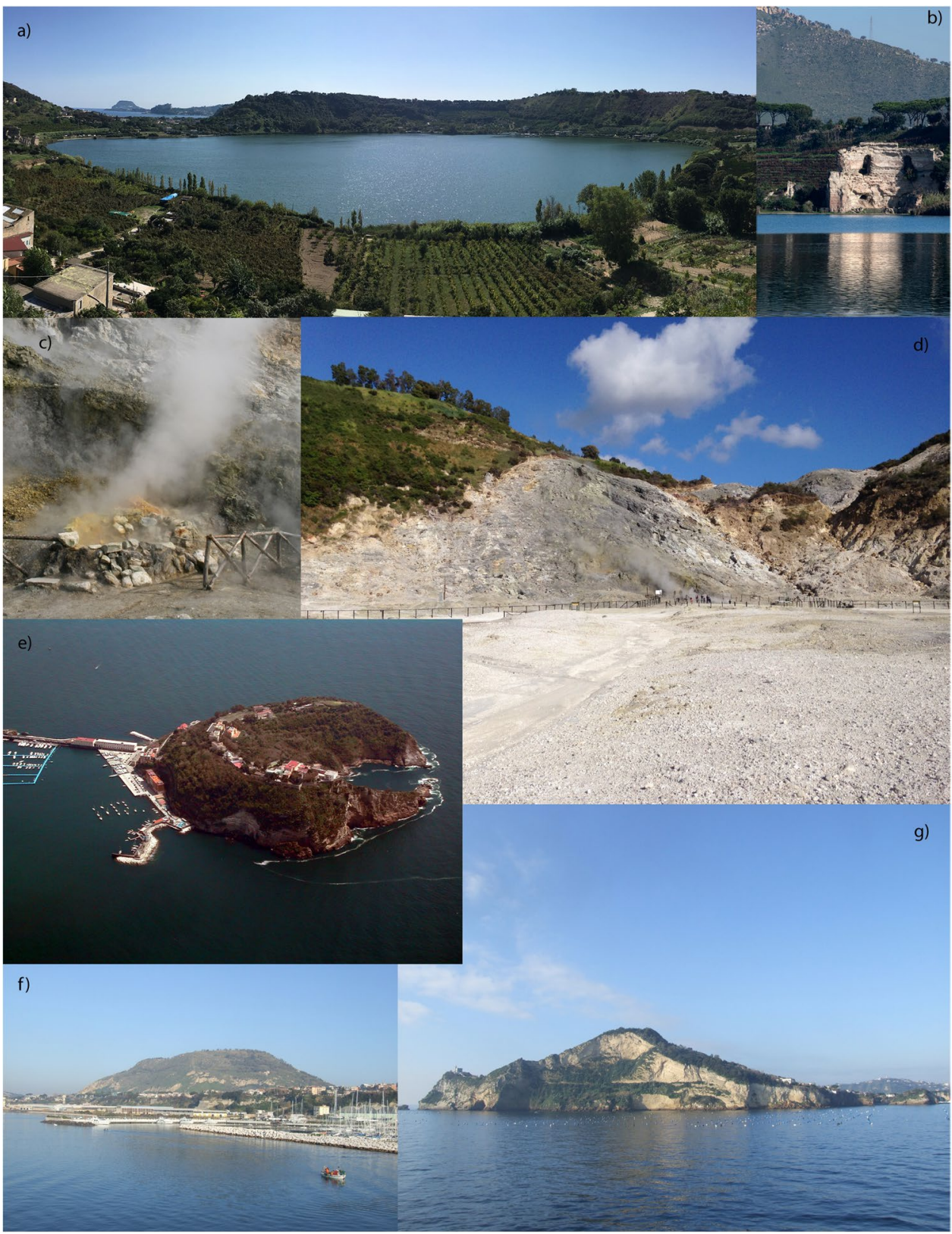

and caldera collapse is inferred to have occurred between the emplacement of the lower and upper members. The deposits suggest that the magma was intermittently in contact with water, generating magmatic and phreatoplinian explosions. The later phases of the eruption were drier, and these dense columns collapsed to form the pyroclastic density currents (PDCs) (Orsi et al. 1992). The zeolitised PDC deposits of this eruption, termed Tufo Giallo Napoletano (Neapolitan Yellow Tuff), form thick outcrops in and around the caldera, and blocks of these indurated deposits were used in construction in the region (Fig. 6). The age of the NYT has been constrained to $14.19 \pm 0.17 \mathrm{ka}$ ( $1 \sigma$; Ramsey et al. 2015 and references therein), and ash from the eruption has been found in sediment cores from the Adriatic Sea and a lake in Germany that is more than $1100 \mathrm{~km}$ away (Bourne et al. 2010; Lane et al. 2015). The eruption led to a collapse of an area $10-11 \mathrm{~km}$ in diameter, within the larger caldera associated with the CI (Scandone et al. 1991; Orsi et al. 1992). The estimates of magma volume based on the thickness and dispersal of the deposits (Orsi et al. 1992; Scarpati et al. 1993) is about $40 \mathrm{~km}^{3}$ and indicates that the NYT was approximately a $M 7$ eruption.

Deposits of eruptions prior to the NYT are found in a few outcrops in and around the built-up area of Naples. There is evidence for at least 9 eruptions between the NYT and the CI deposits (Orsi et al. 1996). These deposits are similar in character and comprised of fine lapilli and ash grade material, and termed Tufi Biancastri as they are a 

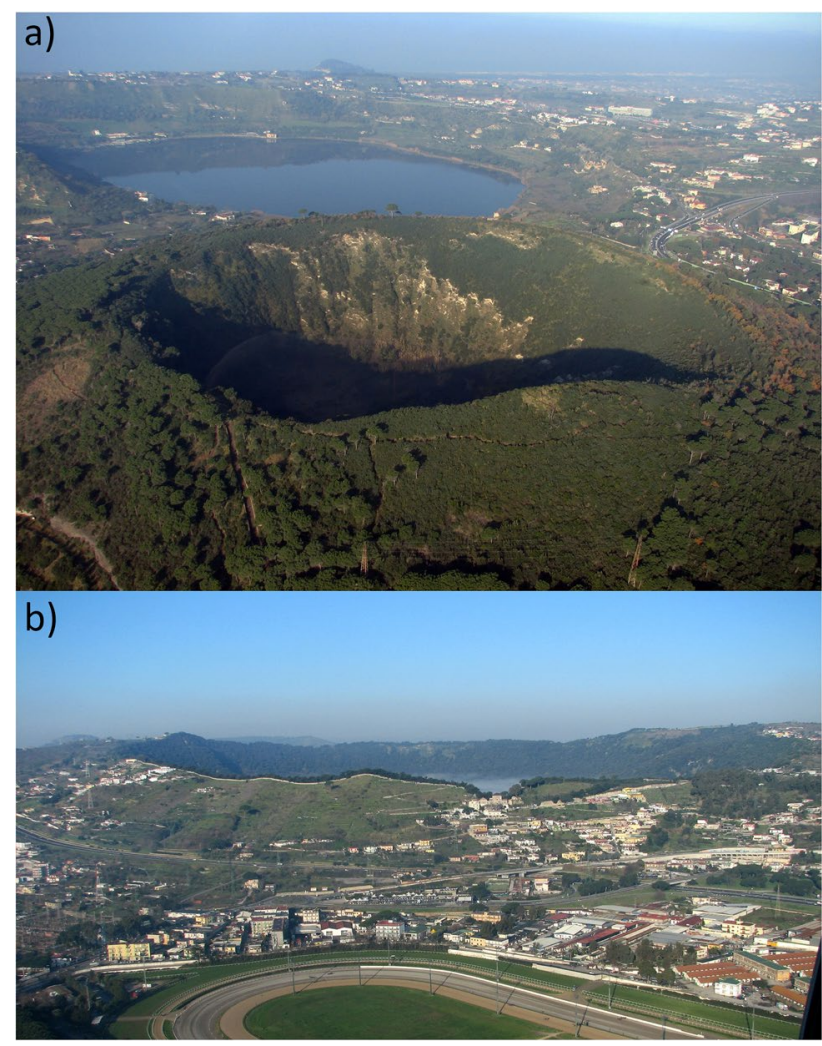

Fig. 5 Photographs of vents of some of the most recent CF eruptions. a The cone that was constructed during the 1538 CE Monte Nuovo eruption; Lake Averno is in the background. b The vent for the seven Astroni eruptions, which are some of the most recent events from the caldera

sequence of whitish tuffs (Di Girolamo et al. 1984; Orsi et al. 1996). Their indistinct characteristics mean that they cannot be easily mapped or correlated over wide areas, and hence, the magnitude and dispersal of these events are poorly constrained. Furthermore, there are not many radiocarbon dates or ${ }^{40} \mathrm{Ar} /{ }^{39} \mathrm{Ar}$ ages for the eruptions to precisely constrain the tempo of the activity. Ash deposited in the distal regions hundreds of kilometres from $\mathrm{CF}$ provides some constraints on both magnitude and chronology. These distal layers have been correlated to CF eruptions based on the chemical characteristics of the glass shards within the ash layers (Wulf et al. 2004; Matthews et al. 2015).

The glass chemistry of distal deposits has identified a CF unit as the source of an ash layer, the Y-3 tephra, which is found in numerous marine cores across the Mediterranean Sea (Albert et al. 2015 and references therein). A detailed study involving glass chemistry and ${ }^{40} \mathrm{Ar} /{ }^{39} \mathrm{Ar}$ ages of deposits from an outcrop in Naples and a sequence extracted from a nearby borehole revealed that the near vent CF deposits are linked to this widespread ash layer (Albert et al. 2019). This confirmed that there was a large eruption from $\mathrm{CF}$ at
$29.3 \pm 0.7 \mathrm{ka}(2 \sigma)$, which has been named the Masseria del Monte Tuff (Albert et al. 2019). Dispersal modelling of the tephra thicknesses mapped over $150,000 \mathrm{~km}^{2}$ indicates that approximately $17 \mathrm{~km}^{3}$ DRE of magma was erupted and that it was a M6.6 eruption (Albert et al. 2019). Given such a large volume of magma erupted, a caldera probably formed during the Masseria del Monte Tuff eruption and the evidence was subsequently destroyed by the NYT eruption.

The distal outcrops on the Campanian Plain and Apennines (Di Vito et al. 2008), along with cores from Lago Grande di Monticchio (LGdM; $130 \mathrm{~km}$ E of CF; Wulf et al. 2004) and the Ionian Sea (215 km N of CF, Bourne et al. 2015; and $270 \mathrm{~km}$ ENE of CF, Matthews et al. 2015), provide a record of multiple eruptions. These include five CF Tufi Biancastri eruptions between NYT and Y-3 and another eruption between Y-3 and CI. Given that only eruptions between 3.5 and $14 \mathrm{ka}$ that are $\geq M 5$ are found in distal records (cf. Smith et al. 2011; Wulf et al. 2004), it is likely that these eruptions are at least M5.

The collapse structure that delineates the edge of $\mathrm{CF}$ formed during the enormous $\mathrm{CI}$ eruption at $39.85 \pm 0.14 \mathrm{ka}$ ( $\sim 2 \sigma$; Giaccio et al. 2017a). A Plinian eruption column was generated during the first phase of the eruption and it dispersed ash to the E and SE (Rosi et al. 1999). This was followed by emplacement of many voluminous PDCs; some of which travelled more than $100 \mathrm{~km}$ from vent and topped topographic barriers that exceeded $900 \mathrm{~m}$ (Barberi et al. 1978; Silleni et al. 2020). The deposits of an early PDC unit are welded close to the vent, forming the distinctive Piperno facies that has abundant fiamme. Blocks from this CI unit were commonly used in construction. Ash from the eruption, including that dispersed from the co-ignimbrite plumes, is found in marine cores from the eastern Mediterranean Sea and in outcrops across Eastern Europe (Smith et al. 2016). The most distal occurrences of the ash are in Russia, more than $2500 \mathrm{~km}$ from the caldera (Pyle et al. 2006). The total volume of the eruption has been estimated to be between 181 and $265 \mathrm{~km}^{3}$ by combining fallout estimates that were modelled using the Fall3D dispersal numerical code (Costa et al. 2012; Marti et al. 2016) with volumes of the PDCs (Silleni et al. 2020). These volumes correspond to M7.7-7.8 and confirm that the $\mathrm{CI}$ is the largest eruption from a European volcano in at least $200 \mathrm{ka}$.

Exposures that extend below the $\mathrm{CI}$ around the caldera are rare. One outcrop close to the northern caldera rim at Trefola (Fig. 3) records the deposits of 12 explosive eruptions (Orsi et al. 1996), suggesting numerous eruptions of CF or the surrounding volcanoes (such as Ischia; Tomlinson et al. 2014) before the CI. Ischia was particularly active prior to the CI with numerous large eruptions (Vezzoli 1988 and references therein; Brown et al. 2008). The CF vents active in this period and their proximal deposits are exposed at St. Martino, St. Eframo, Mt. Echia 
Fig. 6 The Neapolitan Yellow Tuff and Piperno (CI unit) deposits, which were extensively quarried, and buildings they were used to construct. a The Piperno (grey truncated unit in lower left of image) and NYT deposits (upper right) in the Verdolino Valley along the NE edge of the caldera. $\mathbf{b}$ A NYT exposure in the Posillipo cliffs, on the eastern margin of the caldera. $\mathbf{c}$ The mediaeval Castel Nuovo of Naples (also known as Maschio Angioino) that was built in 1279 CE from both the NYT (walls) and Piperno (towers) deposits. d NYT as it appears in the San Rocco (Naples) quarry. e The Piperno (CI) facies is used in the San Marcellino building in central Naples, and $\mathbf{f}$ noticeably for the columns

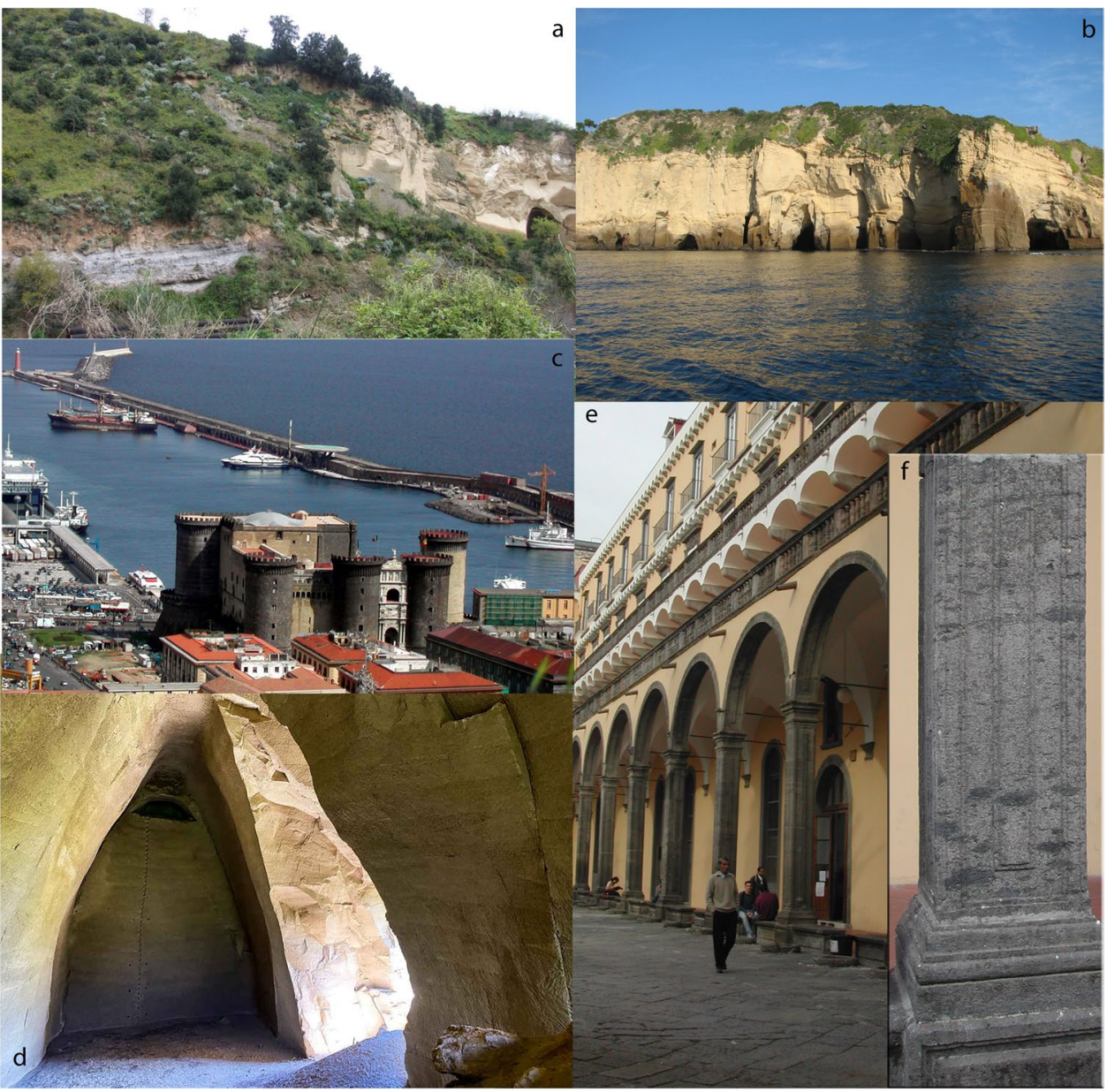

and along the Monte di Procida sea-cliff (Fig. 1). There are also small lava domes, Punta Marmolite and Cuma (Figs. 3, 7), preserved beneath the CI that testify to some extrusive activity (Rosi and Sbrana 1987; Orsi et al. 1996). In addition, other distal records (such as Fucino, $130 \mathrm{~km} \mathrm{~N}$ of CF, Giaccio et al. 2017b) and outcrops on the Campanian Plain, Apennines (Di Vito et al. 2008) and Sorrento Peninsula (De Vivo et al. 2001; Rolandi et al. 2003) record at least seven eruptions between 100 and $290 \mathrm{ka}$ that are likely to have been from CF. The earliest eruptions include the three Seiano Ignimbrites that erupted between around 290 and $240 \mathrm{ka}$ (Rolandi et al. 2003) and the $157 \mathrm{ka} \mathrm{Tau}-$ rano Yellow Tuff (De Vivo et al. 2001). All these pre-CI eruptions are likely to be $\geq M 5$. Furthermore, the eruptions that generated the widespread $109.1 \pm 0.8 \mathrm{ka}(2 \sigma)$ X-6 and $\sim 105.6 \pm 0.5 \mathrm{ka}(2 \sigma) \mathrm{X}-5$ tephra layers (Mannella et al. 2019), which probably correspond to the Durazzano Ignimbrite and the Piano di Sorrento Ignimbrite (Rolandi et al. 2003), are likely to be larger and M6-7. These records indicate that large explosive activity probably started at CF at around $290 \mathrm{ka}$, and there are likely to have been more frequent smaller eruptions, but little is known about these eruptions until after $40 \mathrm{ka}$.

\section{Other Campanian volcanoes}

There are other volcanoes in and around the Bay of Naples that have been active over the life cycle of CF. Ischia Island, located $\mathrm{W}$ of Procida, is a resurgent caldera volcano and the source of many large eruptions before the $40 \mathrm{ka} \mathrm{CI}$, including the widespread $\sim 55 \mathrm{ka}$ Monte Epomeo Green Tuff (MEGT; Vezzoli 1988; Brown et al. 2008; Tomlinson et al. 2014). Since the resurgence began at around $33 \mathrm{ka}$, there have been periods of intense activity with numerous small explosive and extrusive events that have generated spatter and tuff cones, and lava domes and flows (de Vita et al. 2010). Notable events in prehistory and historic times are the $\sim 5.5 \mathrm{ka}$ Piano Liguori, $2.9 \mathrm{ka}$ Cannavale, 60 CE Cretaio (Primerano et al. 2021) and 1302 CE Arso eruptions (de Vita et al. 2010). Monogenetic vents around the islands of Procida and Vivara, SW of CF, were active well before the $\sim 55$ ka MEGT eruption until the 14 ka NYT (De Astis et al. 2004). Several of these deposits are associated with archaeology (de Vita et al. 2010, 2013).

Volcanic activity at Vesuvius, E of CF, starts after the $40 \mathrm{ka}$ CI eruption, with numerous eruptions dispersing 
Fig. 7 Images of Cuma and Sybil's cave. Cuma is located just outside the CI ring structure. a This hill is comprised of an old (pre-CI) lava dome that is overlain by deposits of the CI and the NYT eruption. $\mathbf{b}$ The thick NYT facies were excavated for $\mathbf{c}$ Sybil's cave (wikim edia.org)

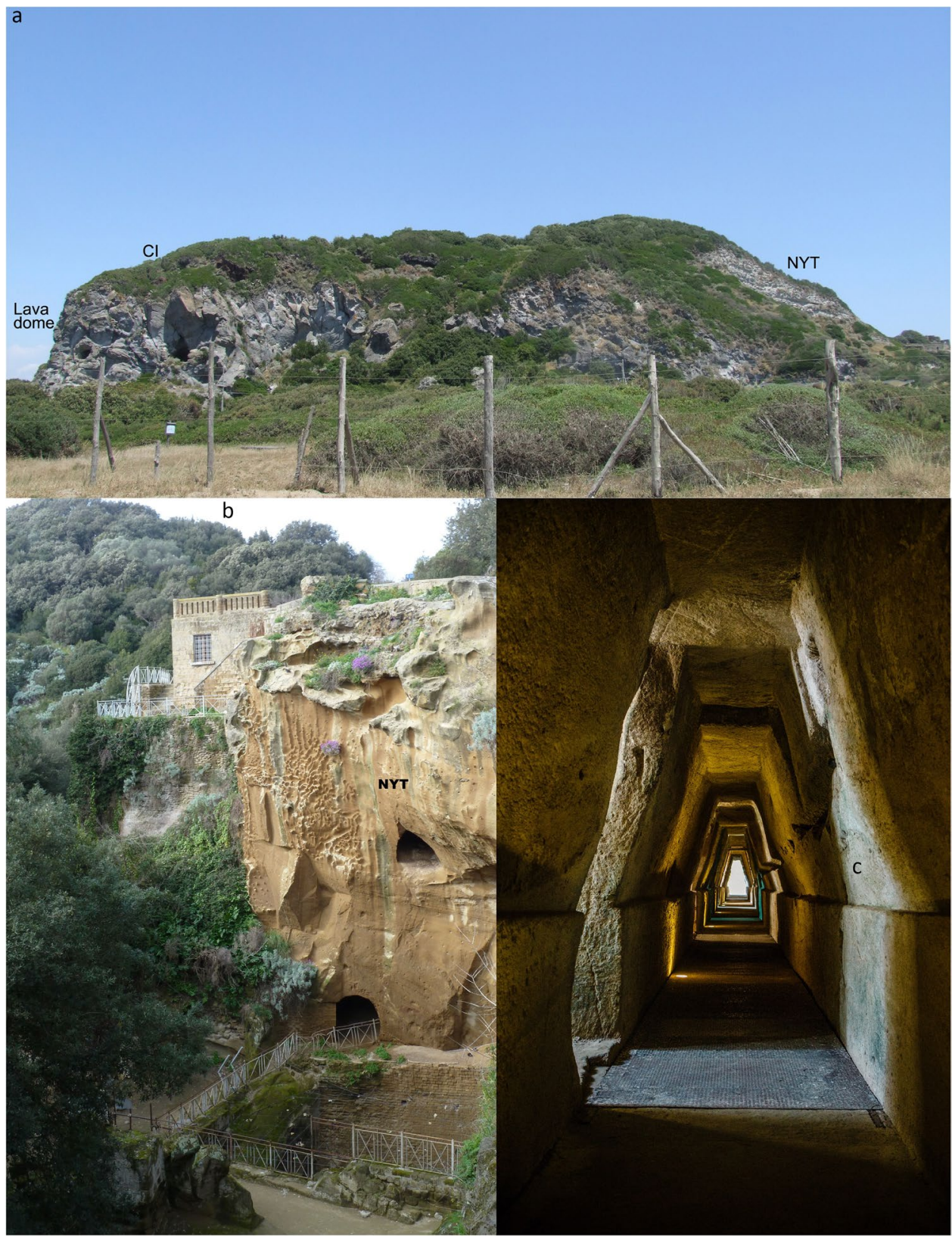

tephra over the region, and others extruding lavas that have constructed the Somma-Vesuvius edifice (Di Renzo et al. 2007; Santacroce et al. 2008). Like those from CF, many of the explosive eruptions of Vesuvius dispersed ash over the Campanian Plain and the Apennines, including the Pomici di Mercato (8.5 ka; Delibrias et al. 1979; Santacroce et al. 2008), Pomici di Avellino (3.9 ka; Di Vito et al. 2009) and Pomici di Pollena (472 CE; Rosi and Santacroce (1983); Sulpizio et al. 2005). These are important isochronous marker layers that are useful for the reconstruction of the palaeoenvironment and palaeogeomorphology at the time.

\section{Volcanic products as raw materials}

The NYT eruption profoundly changed the morphology of the area around CF. Its thick deposits started to be extensively quarried by the Greeks from Cuma (at least since the sixth century BCE) and the quarrying intensified during Roman times. The welded CI Piperno unit was also quarried at those times but it was not as accessible as the NYT (Fig. 6). The proximal NYT deposits were transformed by lithification and alteration that converted the glass particles to zeolites (de' Gennaro et al. 2000). The yellow zeolitised facies, named Tufo Giallo Napoletano, was used for construction due to its easy workability, high 
compressive strength and low weight. The more distal NYT pyroclastic deposits are non-zeolitised and are unconsolidated and grey in colour. The local name of these grey deposits is "pozzolana" or pulvis puteolana, and this was a basic component of the special mortar created in Campania. This term is also used for the material from the more recent eruption deposits of Baia-Fondi di Baia and Astroni. These pyroclastics have a particular resistance and hydraulic properties that are imparted to the mortars made with the material. Vitruvius explained it as "a kind of dust which by nature has extraordinary qualities" which is found in Baia and around Vesuvius, and when "mixed with lime and crushed stones, it makes the masonry so stable that it hardens not only in normal buildings, but also under water" (Vitruvius, De Architectura II, 6; see also Strabo, V, $4,6)$. The extraordinary importance of these pyroclastics for construction is evident in Baia and elsewhere in the $\mathrm{CF}$, where it can be seen in numerous Roman monuments and public and private buildings, such as baths, cisterns, aqueducts and domes. These could not have been built without the special pulvis puteolana mortar (Adam 1988). Recent studies have among other things documented the special composition prescribed by Vitruvius: 1 part of lime as a binder, 2 parts of pozzolana as aggregate and 15 to $20 \%$ water. This corresponds with what was used for Phlegraean monuments such as the Piscina Mirabilis (built between 27 BCE and 14 CE) (Rispoli et al. 2017). The Roman quarries used to extract the pyroclastic material were located along the slopes of Monte di Procida hill and a large quarry was located in an area that is now a district (Ponti Rossi) in the eastern part of the city of Naples. The NYT tuff was also extracted beneath the city of Naples, which generated long tunnels connected to aqueducts used as reservoirs (Fig. 6). Reoccupation of the tunnels in the NYT was improved during World War II so that they could be used as air raid shelters.

\section{Humans and volcanic changing landscape during prehistory}

Occupation of Campania most likely dates back to the Lower Palaeolithic and may pre-date the start of the volcanic activity in the region as hominin fossils dated to $670 \mathrm{ka}$ have been found at Notarchirico, $140 \mathrm{~km}$ E of CF (Pereira et al. 2015). Human footprints were found on ash deposits at Roccamonfina volcano (see Fig. 1), which have been dated to around $350 \mathrm{ka}$ (Panarello et al. 2020 and references therein).

Traces of the Palaeolithic are missing from the CF and Campanian Plain, but this is unsurprising as the $39 \mathrm{ka} \mathrm{CI}$ eruption completely buried and altered the landscape. There are no significant direct stratigraphic relationships for the Palaeolithic phases preceding this eruption. The deposit with lithic industry of the middle Acheulean (Fig. 2) of the Quisisana of Capri (Piperno and Segre 1985) does not preserve an anthropized palaeosurface directly below the eruption deposit, and therefore, this does not represent a significant chronostratigraphic element here. Upper Palaeolithic (Fig. 2) lithic assemblages associated with Mousterian and Uluzzian (Fig. 2) are linked to Neanderthals and have been identified below the CI deposits in Castelcivita cave, $95 \mathrm{~km} \mathrm{SE}$ of CF (Giaccio et al. 2008) and at other sites in southern Italy (such as Grotta del Cavallo, $330 \mathrm{~km}$ ESE of CF; Zanchetta et al. 2018). Proto-Aurignacian (Fig. 2) industries are the latest identified beneath the CI at Castelcivita and in Serino (Accorsi et al. 1979), but far below the palaeosurface covered by CI deposits. Such technology is thought to be associated to anatomically modern humans suggesting that they had migrated into the region before the eruption.

The catastrophic CI eruption completely modified the landscape within $100 \mathrm{~km}$ of CF and covered central and internal parts of Campania in metres of volcanic ash. These areas would have been uninhabitable for decades to centuries but evidence for occupation in the region does not appear until much later, and only observed many millennia after the NYT (14 ka) eruption, during the Neolithic.

The Early Neolithic (Fig. 2) and its Impressed Ware was well established in Campania, but concentrated in internal central-northern Campania. Items are not found across the entire region and only a few have been documented in the coastal areas of Salerno (site Guarne S. Eustachio) and nearby (S. Mauro di Buccino). This distribution implies that the anterior and coastal Campania were not inhabited and suggests strong connections with the Apulian area where the ceramics were developed. There are no clear stratigraphic relationships between Early Neolithic objects and CF eruptive deposits. In most of the excavated sites in the Calore valley (Talamo and De Lorenzo 2008), especially in Campo Ceraso di Torre le Nocelle and in San Martino di Taurasi, the Neolithic levels seem to be above the $\sim 8.5 \mathrm{ka}$ Pomici di Mercato eruption deposits from Vesuvius. However, in all these cases the tephra deposit does not form a clear layer and is often reworked in the soil.

The radiocarbon dates known for the Impressed Ware in Campania are placed in the first centuries of the 6th millennium BCE $(\sim 8 \mathrm{ka})$. In the areas marginally affected by volcanism, Capri is the main and almost the only site of the Middle Neolithic with trichrome pottery that dates to about the 5th millennium $(\sim 7 \mathrm{ka})$. The advanced phase, Serra d'Alto type, of the Middle Neolithic is more common in the region along with the subsequent, Diana type, phase of the Late Neolithic that dates to around the mid-5th millennium BCE $(\sim 6.5 \mathrm{ka})$. The sites of Masseria Sanguigno at Acerra (Talamo 1996) and Piazza S. Maria degli Angeli in Naples (Giampaola and Boenzi 2013) are, for now, the oldest evidence of settlement in these areas, with only the Serra d'Alto type. There are no precise correlations with any volcanic deposits in the Acerra site but in another 
Neapolitan site, these wares are above a palaeosurface directly above the Pigna S. Nicola deposits $(\sim 9.5 \mathrm{ka}$, Di Vito et al. 1999) and below a man-made palaeosol buried by the Ischian Piano Liguori tephra (5.5 ka, de Vita et al. 2010; Talamo 2008a). The association of the two phases of the late Neolithic, Serra d'Alto and Diana, undoubtedly indicates cultural continuity at the sites (Fig. 2). Several sites with this association are reported in the Campanian Plain. At Bellavista di Monte di Procida (Albore Livadie 1986) on the coast of CF, the Serra d'Alto and Diana phases are present and at the Cilento-S. Michele site on Ischia (Buchner 1986) the Serra d'Alto and Diana phases occur with the subsequent Macchia a Mare type pottery of the early Eneolithic phase. Ultimately, the impression is that from the Serra d'Alto phase onwards there has been a slow but steady increase in the occupation of the area and surrounding region. This data may suggest an improvement and stabilisation of settlement conditions, with the formation of numerous fertile palaeosols for which development was not hindered by the frequent volcanic activity of CF.

Occupations during the Eneolithic, i.e. between the Neolithic and the Bronze Age, are present across most of Campania (Talamo 2008a, b; Pacciarelli and Talamo 2011) and include (Fig. 2) the Initial and Early Eneolithic (EE1, aspect of Macchia a Mare; EE2, aspect from the base of the structures of Taurasi and EE3, aspect of Taurasi), Middle (ME, Gaudo) and Late Eneolithic (LE, Laterza aspect). Not much is known about the forms of land occupation during these phases. In the CF area, evidence of the early and middle phases is only observed on the western margins of CF at the acropolis of Cuma (Jannelli 1999) and at Licola (Depuratore-water purifier-and San Severino) (Fig. 3). On the Campanian Plain, the Caivano site (Sottototratta IV, Lot 10, excavations 2003-2004) is of particular importance. There numerous huts with an elliptical or circular plan and hearths were found (Laforgia et al. 2007a). These are possibly related to the Gaudo culture, whose occupation was disturbed, but not completely interrupted, by two closely spaced CF eruptions-Agnano $3(\sim 5 \mathrm{ka})$ and Paleoastroni 2 ( $4.7 \mathrm{ka})$ (Passariello et al. 2010; Talamo et al. 2011). These ${ }^{14} \mathrm{C}$ dates of palaeosols specify the chronology of both eruptions, which are shown to occur within a few years of each other. These two eruption deposits form precise chronostratigraphic and cultural markers and provide a terminus ante quem for the development of the culture of Gaudo, which, despite its importance had, until now, imprecise chronological constraints. In the reconstructed cultural sequence, the Gaudo-type tomb at Parmiano di Acerra represents the most recent context, which is directly buried by the deposits of Agnano 3 ( 5 ka); the date of the Tribal Chief of Madonna delle Grazie in Mirabella Eclano-one of the most important tombs of Gaudo-is placed between 4.8 and $4.6 \mathrm{ka}$. These occurrences indicate that Gaudo had already developed before $4.9 \mathrm{ka}$ and persisted with only a few changes until 4.7-4.6 ka (Talamo et al. 2011).

The Late Eneolithic (Laterza) culture in the Piana Campana appears no earlier than the AMS deposit (Fig. 2), with various huts and numerous tombs on a soil above the tephra in the Gricignano site (Fugazzola Delpino et al. 2003). The ${ }^{14} \mathrm{C}$ dates place this phase of occupation around the $4.5 \mathrm{ka}$ (twenty-sixth century BCE) and thus provide a terminus ante quem for the eruption of AMS and a terminus post quem for the eruption of the Solfatara $(4.18 \mathrm{ka}$; also referred to as Flegrea 1), whose deposits are directly at the top of the dated levels (Passariello et al. 2010; Talamo et al. 2011). The Laterza culture persists on the Campanian Plain (in Gricignano and in Carinaro; Fig. 1), through a series of CF eruptions following Solfatara and up to Astroni 5 (termed Flegrea 2) at around 4 ka (Fugazzola Delpino et al., 2003; Laforgia et al. 2007b). These are particularly good examples of areas where occupation continued despite the areas being covered in CF pyroclastic products. These eruptions undoubtedly caused periods of crisis and damaged houses and cultivated fields, but they apparently were not catastrophic events. This allowed the resumption of cultivation in the years following the eruptions.

In Campania, the passage from the Eneolithic to the Early Bronze Age is marked by the Balkan culture of Cetina (Talamo 2008b), which is documented in a few sites (Fosso Aimone di Atena Lucana and Oliva Torricella in Fuorni di Salerno; Fig. 1) at around 4.45-4.25 ka (25th-23th century $\mathrm{BCE}$ ). Unfortunately, none of these items can yet be directly correlated to volcanic deposits.

The Early Bronze Age in the region is characterised by the facies of Palma Campania, which is observed at numerous sites (Di Vito et al. 2019) and accompanied by cultivated fields and beaten roads (Saccoccio et al. 2013). During this period, there is a well-structured human landscape that was widespread and spanned different environments, with settlement densities akin to those in the Roman age (Talamo 1998; Talamo and Ruggini 2005). There are numerous and extensive sites on the Campanian Plain and some have been documented within CF (such as Quarto, via Masullo). The Vesuvian 3.9 ka Pomici di Avellino eruption was a catastrophic event for the facies of Palma Campania (Di Vito et al. 2019), with settlements within $70 \mathrm{~km}$ of the vent showing an immediate and definitive interruption. Continuity of occupation is only found only in the marginal areas, primarily the coastal area of the Gulf of Naples, close to Vesuvius (S. Abbondio in Pompeii) and in the Phlegraean area (Piazzale Tecchio, Naples; via Masullo, Quarto), and at other sites where the ash thickness is $<30 \mathrm{~cm}$ (such as La Starza di Ariano Irpino).

There is evidence for reoccupation of Campanian Plain sites that were affected by the Pomici di Avellino 
eruption (Masseria Rossa at Nola, S. Paolo Belsito; Fig. 1), but it was limited and short lived. The reoccupation occurred on the order of years to decades and was related to the Palma Campania facies once again. The pottery had the same character as the later Proto-Apennine (S. Paolo Belsito), but there was not much of it and it disappeared rapidly. This seems to show that, despite the relatively quick recovery of the natural environment, the destruction of the rural landscape and the settlement organisation prevented the Palma Campania people reinhabiting the area. In the surrounding areas, the subsequent Middle Bronze 1-2 (Proto-Apennine) phase is well documented, and it implies direct cultural continuity with the previous Palma Campania facies. This phase is also present in and around $\mathrm{CF}$ and well documented in a settlement on the island of Vivara (Procida) that begins with an early phase of the Proto-Apennine (termed Punta Mezzogiorno; 3.75-3.85 ka, ca. 19th-eighteenth century BCE) and continues uninterrupted until the Apennine (Middle Bronze Age 3; $3.25 \mathrm{ka}$, fourteenth century BCE). This site is particularly important in Mediterranean prehistory, as in the Proto-Apennine period some items from the Mycenaeans are documented, implying that this area was a hub for the exchange of Aegean and western Mediterranean items. Unfortunately, no direct stratigraphic relationships between the items and the volcanic deposits are known at this site.

On the Campanian Plain, attempts of reoccupation following the eruption of the Pomici di Avellino are found with the deposits of the $\sim 3.5 \mathrm{ka} \mathrm{AP1}$ and AP2 eruption deposits from Vesuvius (Di Vito et al. 2013). In the palaeosol covered by the AP1, there are documented levels of occupation still associated with the facies of Palma Campania, and in the palaeosol covered by the AP2, the recovered items record the transition from Palma Campania to Proto-Apennine. These Vesuvian eruptive events (AP1-2) may have contributed to settlement instability and led to the abandonment of these areas over prolonged periods of time (see the site of S. Abbondio at Pompeii).

Thanks to the many samples from archaeological sites, the date of the Pomici di Avellino eruption is well constrained to $3.9 \mathrm{ka}$, while the two eruptions AP1 and AP2 are placed within the following centuries (Passariello et al. 2009; Di Vito et al. 2013, 2019). The subsequent period, called the Apenninic (Middle Bronze Age 3), shows fair diffusion across and notable development within the region. Palma Campania sites on the Campanian Plain start to be continuously occupied again in this period, but settlements were slightly smaller and the population density was lower. Sites in CF show more evidence for stable occupation in the Apenninic (e.g. Pozzuoli, Montagna Spaccata: Albore Livadie 1986) along with Ischia and Vivara. There are no radiometric dates for the Apenninic, but the relative chronology suggest that it dates to 3.45-3.55 ka (fifteenth and fourteenth centuries BCE; Fig. 2). Even less can be said, both in the CF and on the Campanian Plain, for the subsequent phases - the Recent and Final Bronze Age that are referred to as the Sub-Apenninic and the Protovillanovan, respectively. The Sub-Apenninic in Campania follows the Apenninic and it is difficult to distinguish. The Late Bronze Age, on the other hand, seems to mark a substantial cultural and settlement break with the previous period. There have been a few recent discoveries in the region that will provide more insight into this period in the future. As far as we are concerned here, there are no direct correlations with volcanic events for these last phases of the Bronze Age, as is the case for the subsequent Iron Age and the Greek and Roman age, which are of great importance for the CF. These occurred in the long period of quiescence of the $\mathrm{CF}$ that began around $1550 \mathrm{BCE}$ and spanned three millennia (Fig. 2).

\section{Human and volcanic changing landscape during history}

The city of Pozzuoli in central CF was founded in $528 \mathrm{BCE}$ by a group of Greek exiles from the island of Samos who gave it the name of Dicearchia, which translates to Place of Justice. This settlement is built on the promontory of the current Rione Terra, a district of Pozzuoli, and remained in the political orbit of Cuma until 421 BCE. At that time, the whole $\mathrm{CF}$ area fell under the dominion of the Campania populations, and later, in $338 \mathrm{BCE}$, under the influence of Rome. During the Second Punic War (217-200 BCE), the Roman general Quintus Fabius Maximus fortified the village of Dicearchia to defend the Phlegraean coasts from Hannibal, who had already taken over the city of Capua. After the war in 197 BCE, Dicearchia became a Colonia civium Romanorum and its name changed from Greek to the Roman one of Puteoli (Fig. 8). This name may derive either from puteus (well), due to the numerous wells in the area that were excavated to release the winds trapped in the subsoil which, according to the Aristotelian theory, were the cause of frequent earthquakes, or for the puteo (stench) in the city (Varro: De lingua latina 23,25; Strabo: V, 4, 6). Since the late second century $\mathrm{BC}$, the beauty of the landscape and the large number of thermal springs attracted interest from the rich Romans who built luxurious residences in the CF area. In addition, the region was known to have particularly good fishing off the coast and extraordinarily fertile volcanic soil. Along the entire coastal strip (called Ripa puteolana, or simply Ripa; Fig. 8), a rapid urban expansion occurred within a few decades, as evidenced by the Lex parieti faciendo epigraphic document of $105 \mathrm{BCE}$. Puteoli became one of the main ports of the Mediterranean, connecting the maritime traffic between Rome and the East. In fact, as early as 126 BCE the Latin poet Lucilius called it Delus 
Fig. 8 a Drawing of Puteoli and Ripa puteolana (De Hollanda 1541) in central CF. b The reconstructed ground displacement through time in Pozzuoli at benchmark 25 , reported in Fig. 3 (note the break in time between $35 \mathrm{BC}$ and ca. 1150 CE; modified after Del Gaudio et al. 2010 and Di Vito et al. 2016) around the b Mont Nuovo eruption, and $\mathbf{c}$ in the last century

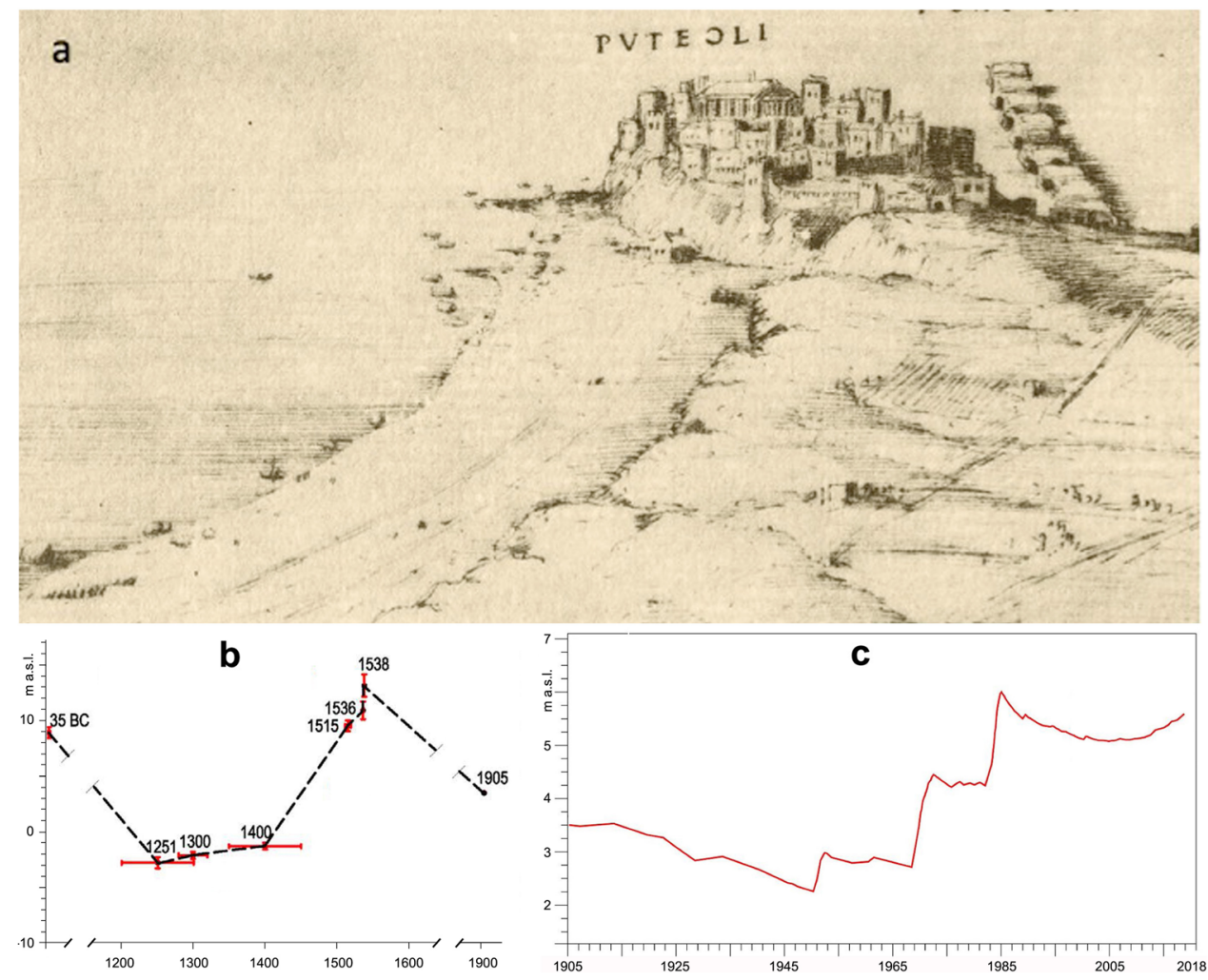

minor, which implies it was the smaller (or latest) Delos-a Greek city that was famous for extensive trade across the Mediterranean.

The Baia settlement (Fig. 9) near Puteoli was an appreciated resting place of the Roman patricians. Baia and Puteoli could communicate through the Via Herculanea, a thin strip of land that separated Lake Lucrino from the sea, and described by Strabo (see Fig. 3). This embankment of beaten sand was about $1.5 \mathrm{~km}$ long and "wide enough for a car to pass" and it was believed to be ancient and built by Hercules on his return from Spain. In the late Republican age, Lake Lucrino was used for fish and oyster farms. Under Julius Caesar (101-44 BC), fish farmers asked to refurbish this embankment, which was then called Opus Iulium in honour of Caesar. This is described by Servius Marius Honoratus (fourth century $\mathrm{CE}$ ) in the Commentaries of the Aeneid as follows: "In the gulf near Baia, in front of the city of Pozzuoli, there are two lakes, Averno and Lucrino. Once upon a time in these lakes there were so many fish that the fishermen drew great catches and paid great tributes to the treasury. But often during the storms the sea broke into the lakes with great impetus and allowed the fish escape, which was detrimental to the fishermen. Thus, they requested Gaius Julius Caesar, by order of the Senate and with public expenses, closed a part of the sea so that a small inlet remained. In this way, there was an abundance of fish in the lake, and the sea waves were no longer harmful" (Mc Donough et al. 2004).
During the Civil War, Octavian Augustus (63 BCE-14 CE) delegated Marcus Vipsanius Agrippa to prepare a military fleet and build a port due to the continuous raids along the coasts of the peninsula by Sestus Pompeus. In $37 \mathrm{BCE}$, Agrippa identified the area of Lake Avernus and Lucrinus as a strategically suitable site for the military base for the fleet. The two lakes were connected to each other and to the sea by means of artificial canals. With appropriate barriers about $6 \mathrm{~m}$ high, Lake Lucrino was incorporated into the complex structure of the Portus Iulius, which Octavian

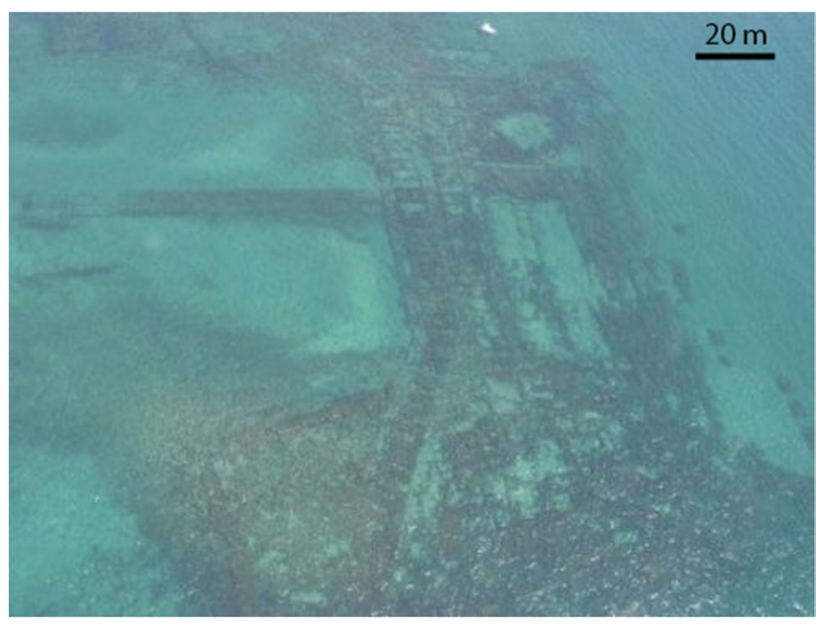

Fig. 9 Aerial view of ruins of the town of Baia that are now submerged due to negative bradyseism (i.e. subsidence) 
named in the memory of his uncle, the great Julius Caesar. The canalization of Avernus waters is remembered by Virgil in the Georgics: "Or will I remember the ports and dams added to Lake Lucrino and the sea that is indignant with great screeches, where the water of Portus Iulius resounds far from sea that pours, and the stormy wave of the Tyrrhenian is introduced in the waters of the Averno?" (Publius Vergilius Maronis, first century BCE). In addition to the canalisation, Augustus commissioned an aqueduct (Aqua Augusta), which extended over $100 \mathrm{~km}$ and exploited the volcanic morphology so that it crossed the Phlegraean area without the need for many bridges.

In the wake of these great structures, Augustus gave Puteoli a strong constructive impetus and imposed an urban plan. This resulted in restructuring of the city with the demolition of buildings and the construction of regiones and vici, on the model of Rome. The colony developed considerably along the Ripa (Fig. 8) with the construction of two suburbs: the vicus Lartidianus and the vicus Annianus. These were suburban neighbourhoods reserved for Nabataean Arab foreigners in Pozzuoli. In this historical context, the Colonia Puteoli became Colonia Iulia Augusta Puteoli. This urban expansion and traffic along the Ripa barely coexisted with the military at Port Iulius, as these led to the naval base being transferred to Misenum in 12 BCE. Logistic structures of Port Iulius were converted and, together with the port of Puteoli, became a single commercial port area. Puteoli quickly reached its economic and commercial peak and even hosted the fleet that supplied Rome with wheat (Cura Annonae) from Alexandria, which played for a long time a primary role in commercial traffic with the East. Meanwhile, Misenum remained the most important imperial military port. Following the eruption of Vesuvius of $79 \mathrm{CE}$, a stream of refugees from Pompeii and Herculaneum settled in Naples, Puteoli and Cuma (Scandone et al. 2019).

The fortune of Puteoli, however, gradually began to wane between 42 and $54 \mathrm{CE}$ due to the construction of the port of Ostia at the mouth of the Tiber River in Rome. Further expansion of Ostia Port under the Emperor Traianus (98-117 $\mathrm{CE})$ led to even greater decline. When the Emperor Commodus (161-192 CE) moved the Alexandrian fleet to Hostia, Puteoli lost the maritime commercial monopoly. Nevertheless, the Puteoli economy still survived flourishing in the trade of luxury goods and pozzolana with the East. Puteoli continued to be a rich merchant city until the end of the Western Roman Empire, in the fourth century CE. When Constantinus built the new capital Nova Roma in Bisantium (330 CE), the fleet of Misenum was moved to the Bosphorus, leaving only light boats to defend the western Mediterranean and the Phlegraean coasts from pirates. Even when the port of Misenum was decommissioned by Theodoric in the fifth century CE, despite the evident signs of decay, Puteoli remained a centre of great interest. This is evidenced by the restoration in $399 \mathrm{CE}$ of the Serinus waterworks that served the city and the presence of aristocrats, that continued to frequent their luxurious villas for otium et delectatio, such as Quintus Aurelius Symmachus (380 CE).

In the 5th-sixth century $\mathrm{CE}$, the Phlegraean area went into a state of social and economic decline due to the continuous barbarian incursions, including those of Alaric (410 $\mathrm{CE})$ and Genseric (455 CE), and the disastrous eruption of Vesuvius in 472 CE. Furthermore, the gradual sinking of the Puteolan coast due to bradyseism swamped the Ripa and was accompanied by malarial epidemics. Following the invasion of Totila, king of the Ostrogoths, in 545 CE, Puteoli was devastated. The surviving inhabitants were forced to leave the lower part of the city and they took refuge in the Rione Terra (Terra murata) which, surrounded by walls, became the Castrum puteolanum. Despite the heavy setback in the city's economy and its importance, Puteoli remained a popular agricultural and fishing centre (Annecchino 1960).

Between the ninth and tenth centuries, there were frequent raids along the coasts by Saracens, who conquered and destroyed Misenum. In 915 CE, Cuma also fell and became a den of pirates and marauders for centuries. In the eleventh century, the Arab geographer Al-Idrisi mentioned the centres of Campania in his Opus Geographicum-the only epithet attributed to Puteoli was that of cashtili (castle), while the other centres such as Naples, Cuma and Misenum were described in detail.

Little is known about the twelfth century, except for the detachment of Puteoli from Naples. Despite having no other data concerning the thirteenth century, it is plausible that the urban settlement of Rione Terra, for the first time called Puzoli by the chronicler Riccardo da San Germano (1227 $\mathrm{CE}$ ), assumed the appearance of a peninsular promontory connected to the mainland by a drawbridge that connects the town with the hinterland (Garufi 1937). In $1266 \mathrm{CE}$, with the defeat of Manfredi in Benevento by Charles I of Anjou, the Phlegraean area passed under the rule of the Angevin dynasty. The slow but continuous recovery of Puteoli began following this historic event. Charles II of Anjou also freed Puteoli from feudal subjection in $1296 \mathrm{CE}$, allowing it to govern itself as a state-owned city (Universitas) with tax concessions. This led to a rapid increase in the number of inhabitants, expanding from 290 residents in $1268 \mathrm{CE}$ to over 2500 in 1489 CE (Giamminelli 1996). Thermal enterprises also received a big boost and new treatment facilities were built in the area, such as the one in Tripergole that had 120 beds to assist a multitude of languishing strangers (De Criscio 1895). During the subsequent period of Aragon domination (1442-1503 CE), several earthquakes were felt in Puteoli and these led to depopulation and had strong repercussions on the economy. The tax reliefs and exemptions granted first by Alfonso I and later by Ferdinand I did not help (Annecchino 1960), and at the end of 
the fifteenth century CE the social and economic life of Pozzuoli regressed. Numerous seismic tremors were felt in the early 1500 s CE, and these were accompanied by strong uplift (positive or ascending bradyseism). These phenomena culminated in the eruption of Monte Nuovo in 1538 CE (Parascandola 1946). The eruption generated the Monte Nuovo cone and buried the area between Lake Lucrino and Lake Averno (Figs. 4 and 5), including the village of Tripergole: "Where today is the Montagna Nova, before the fire, it was mostly sea, nor very far from the water there was a village, and in the times of baths it was very inhabited: there were many hospitals for the poor who came to take baths: there was also an ancient bath of beautiful architecture, which all things today the mountain keeps them buried of ash" (De Criscio 1895).

\section{Documented history of the volcanic activity}

\section{Reconstruction of bradyseism}

Recent bradyseismic crises accompanied by earthquakes occurred in 1969-1972 and 1982-1984, but there is also a wealth of evidence for those that ensued in the last few thousand years. There are many Roman ruins submerged at various depths in the Pozzuoli area and along the entire Phlegraean coast. The most symbolic monument is certainly the so-called Serapeum (Temple of Serapis), whose marble columns have marine Lithophaga bivalve mollusc borings along them. This structure is one of the greatest examples of a Roman Macellum (indoor market). It was built between the end of the 1st and the beginning of the second century $\mathrm{CE}$ and restored at the time of the Severi dynasty (third century CE). A drawing of the columns is the frontispiece in one of the Principles of Geology volumes published by Scottish geologist Charles Lyell between 1830 and 1833 CE (Fig. 10). Lyell commented that the columns of the Serapeum and the geology of cliffs around Pozzuoli provided evidence for two substantial changes $(>6 \mathrm{~m})$ in the relative sea level within the previous millennia. The mollusc borings have been used to form a detailed reconstruction of the ground movement over the last 2000 years in Pozzuoli. Geoarchaeological studies at other coastal sites reveal complex spatial and temporal disarticulation of the bradyseismic phenomenon, both in subsidence and in uplift (Di Vito et al. 2016 and references therein).

The first reference to a possible ground uplift in the Phlegraean area in historical times is synchronous with the 79 CE eruption of Vesuvius. Pliny the Younger, in his second letter to Tacitus many years after the eruption, reported this from his observation point in Misenum: "Certainly the coast had widened and many fish remained dry" (Pliny the Younger, Letters, VI, 20). Starting from the second century $\mathrm{CE}$, subsidence is noted and evidenced by fill deposits in buildings and bath complexes along the coast and repairs at the port. These restoration interventions extended their functionality until the end of the fourth century CE. During the fifth century, the descending bradyseism affected the whole coast and, based on radiocarbon dates from the Serapeum column molluscs, reached its maximum levels $(\sim 6.30 \mathrm{~m}$
Fig. 10 Frontispiece of Lyell's 1830 Principles of Geology book, which depicts the partially submerged Temple of Serapis and its pillars with Lithophaga mollusc borings (left), and (right) a recent photo of the ruins in Pozzuoli

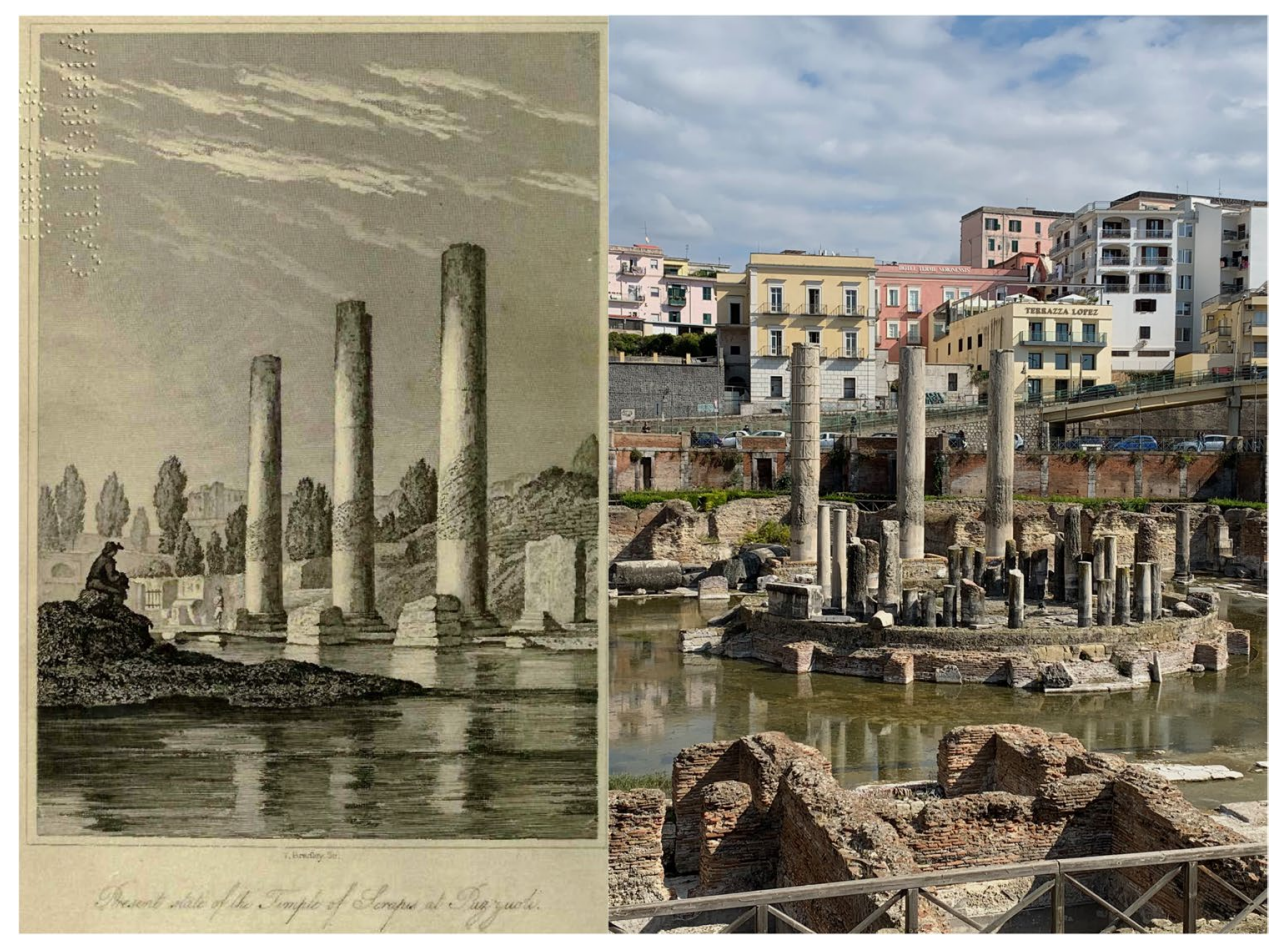


below the current mean sea level) towards the middle of the sixth century CE (Morhange et al. 1999; Todesco et al. 2014). Two tombs were found within the filling of the apse of the famous Imperial Nymphaeum of Punta Epitaffio in Baia. These graves in amphora were placed in the fill that covered the statues of Ulysses and Baios and date from the 5 th to the beginning of the sixth century $\mathrm{CE}$, when subsidence was at its maximum.

At the end of the sixth century CE there was an apparent pause or reversal in the ground movement, and in the eighth century CE the subsidence began again. We have no information about the duration of this phase of negative bradyseism, but it is thought to have continued until the end of the tenth century CE (Di Vito et al. 2016). An apocryphal text of the Acts of the Apostles, datable to that period, describes the submergence of the ruins of the Ripa (Frederiksen 1977). From the eleventh to the twelfth century CE, a phase uplift began, probably accompanied by earthquakes-evidenced by the collapse of columns and alluvial deposits in the Serapeum and in the temple of Mercurius. This phase could have culminated with the strong phreatic activity that was reported around Solfatara in 1198 CE (Scandone et al. 2010), as reported by Scipione Mazzella: "This city was again severely damaged by very serious earthquakes, so it is not known who harms it most, if the insults of the barbarians or earthquakes". In the year $1198 \mathrm{CE}$, during the reign of Frederick II, it was reported that: "Solfatara threw out a big fire with very large globes of stones, which damaged the whole town and at the same time it suffered an earthquake that no building that could not feel so everything was shaken and damaged" (Mazzella 1591). Subsidence again resumed during the thirteenth century CE. Nicolò Jamsilla who was a family member and secretary of the king of Sicily and Apulia, Manfred of Swabia, narrated the siege of Naples in $1251 \mathrm{CE}$ and defined the Phlegraean town as "a place surrounded by the sea and inaccessible mountains" (Jamsilla 1258). Benjamin of Tudela, who passed through Puteoli in $1265 \mathrm{CE}$, described the state of the places as follows: "The sea has risen and covered the city on both sides, and today you can still see the ruins of the markets and towers that once stood in the middle of the city" (de Tudela 1270).

We do not know if the Phlegraean area was substantially affected by the earthquakes that were felt on Ischia in 1228 $\mathrm{CE}$ and $1275 \mathrm{CE}$, or by the Ischian eruption of the Arso in 1302 CE. However, in 1341 CE Giovanni Boccaccio, who was visiting the Phlegraean area, noted that the sea broke into Lake Avernus and Lake Lucrino, and that its breakwater was destroyed. He stated that Via Herculanea disappeared, and one had to take the Via Domitiana to reach Baia.

Between the fourteenth century and the first half of the fifteenth century, the Phlegraean coast continued to be submerged. All the current lower part of Pozzuoli was invaded by the sea-Lucrino dam submerged and Lake
Avernus was in free communication with the sea so that small and large ships could access it (Jacono 1942). An image dating to before $1499 \mathrm{CE}$ shows the Cantarello bathroom (De Balneis Puteolanis, Edinburgh Codex, sheet 3v) and the columns of the Serapeum and the Ripa in the sea (Figs. 9 and 11).

A radical change took place from the second half of the fifteenth century. A series of strong earthquakes accompanied a new phase of uplift. Following the serious damage suffered on the Rocca (Rione Terra) in 1503 CE, the people of Puteoli asked King Ferdinand II of Aragon for permission to build their houses in a safer place. This led to the first expansion outside the city's walls, and the lands that emerged on the coast where the sea was drying up were assigned state property of Puteoli. The numerous earthquakes had damaged buildings on the Rocca to the point that they needed to be rebuilt. The Sant'Agnese and Sant'Agata churches were demolished and replaced with the church of Santa Maria delle Grazie (1512 CE), built on the new marina in the village. The bradyseismic phenomenon and the increasingly frequent earthquakes continued until $1538 \mathrm{CE}$, the year in which the eruption of Monte Nuovo took place (Figs. 9b and c). This eruption was heralded by many long- and short-term precursors, most noticeably the ground deformations and earthquakes and changes to the geothermal system. Editions of the Balneis Puteolanis, which documented the thermal baths and published from the 13th to the fifteenth century $\mathrm{CE}$, testifies that the area in the central-western part of CF was thermally active before the eruption, especially in the Tripergole area, signalling the large availability of high temperature fluids in the lead up to the Monte Nuovo eruption.

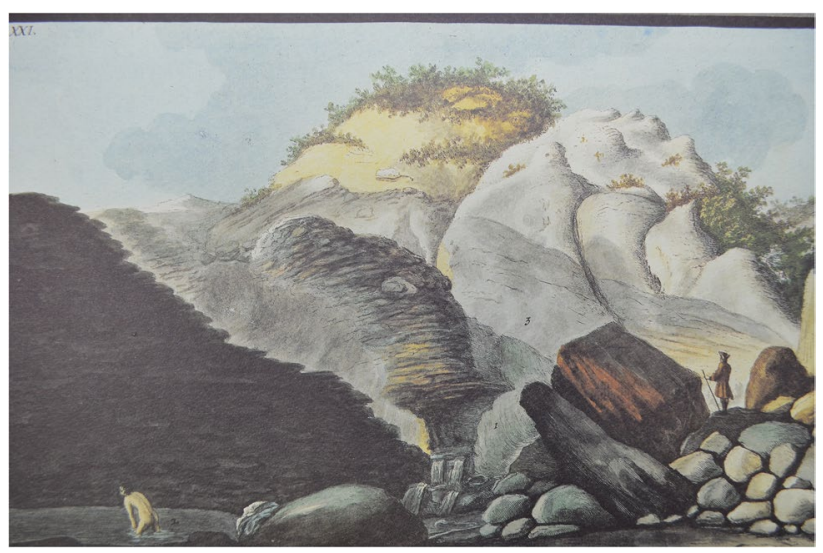

Fig. 11 The Bolla Baths of Pozzuoli da Campi Phlegraei (1776), which was included in William Hamilton's "Campi Phlegraei. Observations on the volcanos of the Two Sicilies". Hamilton was the British envoy to the Neapolitan royal court and made observations of the volcanoes in Naples, which he communicated to the Royal Society of London 


\section{The eruption of Monte Nuovo}

Various historical sources provide a detailed account of the Monte Nuovo eruption that began on the 29 September 1538 $\mathrm{CE}$, and the precursors that commenced years before the eruption are documented above ("Reconstruction of bradyseism" section). Earthquakes were commonly felt in the city of Pozzuoli from 1536 CE onwards, and these became more frequent and intense 3 months before eruption (Parascandola 1947; Guidoboni and Ciuccarelli 2010 and references therein). In the evening of the 27 September, seismic swarms began and they continued until noon on 28 September. The general ground uplift that commenced around 1400 CE became localised to the area when the vent appeared around 2 years before the eruption (Di Vito et al. 2016). In the $36 \mathrm{~h}$ that preceded the eruption, there were metres of ground deformation. Uplift occurred around the coast that effectively extended the coast by $\sim 370 \mathrm{~m}$ (recorded as 200 Neapolitan steps) and stranded fish above water that were collected in "cartloads", and subsidence was recorded in the area where the vent later emerged (Parascandola 1947; Di Vito et al. 2016; Di Napoli et al. 2016). These phenomena led to the exodus of people from Pozzuoli to Naples in the afternoon of the 28 September. Later, in the evening, the first eruptive vents formed on a fracture that started in the Fumose area and extended towards the village of Tripergole (Scandone and Giacomelli 2019; Di Napoli et al. 2016). The Monte Nuovo eruption was fed by three vents and was characterised by three phases separated by pauses in activity. The main vent (MV) formed the crater of the Monte Nuovo tuff cone, and two minor vents were located on the southern (SV) and northeastern (NEV) slopes of the cone. The entire Monte Nuovo sequence includes five members: A (base) to E.

The eruption began at $7 \mathrm{pm}$ on 29 September 1538 $\mathrm{CE}$, and its first phase, which was the main phase, lasted exactly 2 days. Almost continuous phreatomagmatic explosions dominated during this phase, but there were subordinate magmatic explosions that produced shortlived low eruption columns that generated PDC deposits and minor fallout beds. This phase deposited members A and $\mathrm{B}$. Member A erupted from the MV and consists of a sequence of fine- to coarse-ash beds which make up most of Monte Nuovo tuff cone. Member B sits on an unconformity developed on A and is only found in the southern sector of the cone. It is composed of undulating ash beds generated by phreatomagmatic explosions from the SV. The first phase ended with Strombolian explosions at the SV and NEV, which deposited the sequence of coarse scoria fallout deposits dispersed over narrow areas around the eruption vents (member $\mathrm{C}$ ). This phase was followed by a pause in activity that lasted 2 days, and the eruption resumed at $4 \mathrm{pm}$ on 3 October and continued until the following night. It was characterised by low-energy phreatomagmatic and magmatic explosions from the MV, which deposited a sequence of coarse pumice and scoria fallout and laminated to massive ash dilute PDC deposits along the slopes of the cone (member D). The third and last phase of the eruption began at $4 \mathrm{pm}$ on 6 October and lasted for a few hours. This activity was characterised by discrete low-energy explosions through a small dome that had extruded from the MV during the pause in explosive activity. They formed member E, which includes dense to poorly vesicular, angular dark clasts that are found along the slopes of Monte Nuovo. During the last phase, 24 people died while climbing the slopes of the new cone following the second pause in the explosive activity. The Monte Nuovo cone generated during the eruption is $132 \mathrm{~m}$ high and has a basal diameter of $\sim 1200 \mathrm{~m}$ (Fig. 5b).

Pozzuoli remained partially uninhabited for the months following the eruption. Citizens were encouraged to return to the city by the viceroy Don Pedro from Toledo. He ordered the construction of the Don Pedro palace in Pozzuoli and rebuilt the Via Herculanea destroyed by the eruption. He also restored the old tunnel that crossed the hill of Tritoli near Nero's stoves (still active as a popular thermal destination today) and led to Baia. To further encourage repopulation of Pozzuoli, tax exemptions were put in place that lasted until 1567.

Among the secondary effects of the eruption, there was the formation of mofetes, which emitted carbon dioxide through fractures in the soil. In unventilated places, such as caves, the $\mathrm{CO}_{2}$ became concentrated in pockets that extended a few centimetres from the ground since the gas is denser than air. The first reference to one of these mephitic caves, identifiable as the Grotta del Cane, is by the Dominican Leandro Alberti in his work Descrittione di tutta Italia, written in 1542 CE. The Grotta del Cane was well known even in the centuries that followed, and during the eighteenth century CE the phenomenon attracted the curiosity of many visitors that arrived in Naples on the Grand Tour. This phenomenon in the cave generated a heated scientific debate on the nature of this gas that created suffocation but was not poisonous. Sir William Hamilton, English ambassador to the court of Naples from 1764 to $1800 \mathrm{CE}$, measured the dimensions of the cavity with great precision, which is 12 feet long and 4 feet high (i.e. $3.6 \mathrm{~m}$ by $1.2 \mathrm{~m}$; Fig. 11). The cave was also mentioned by Wolfgang Goethe in his "Journey to Italy". Alexandre Dumas père, who wrote "Le Corricolo" on his impressions of Naples, recounts the episode where the dog used by the guide for the experiment fled in front of the tourists to avoid this lethal test. In the nineteenth century, through progress in chemistry, it was established that the mephitic area of the cave was linked to the release of carbonic acid, normally dissolved in water and that it was in the free state in the cave in the form of gas. 


\section{Volcanic legacy}

\section{Natural reserves, craters and lakes}

The main volcanic legacy of CF are the massive fault scarps that delineate the caldera, tuff cones, lakes in craters, thick exposures of volcanic deposits and unique ecosystems. In order to preserve these features, a Regional Park was created in 2003 (Law no. 33 of 1/9/1993 of Campania Region) that extends from the coast to the Leucogei mountains. It hosts a variety of unique flora and fauna and a beautiful landscape, which includes the cones of Astroni (a World Wildlife Fund for Nature (WWF) oasis), Solfatara, Monte Gauro and Monte Nuovo, and the volcanic lakes of Avernus, Lucrino and Fusaro (Figs. 4, 5, 6, 7 and 8).

The CF landscape is dominated by the Camaldoli hill at the northeastern boundary of the caldera. Camaldoli is the highest point of CF (458 m asl) and from there the Regional Park is visible as well as the city and the Gulf of Naples, the Vesuvius stratovolcano and the island of Capri. Along its southern, high-angle slopes, which are remnants of the caldera fault scarps, a 350 m-thick pyroclastic sequence is exposed. It includes at its base the Tufi di Torre Franco, which are the deposits of explosive pre-CI eruptions from the CF and other volcanoes (Rittman 1950; Rosi and Sbrana 1987; Orsi et al. 1996). These tuffs are overlain by the Campanian Ignimbrite, the Tufi Biancastri, NYT and recent eruption deposits. On top of Camaldoli hill is the Eremo dei Camaldoli, a hermitage established in $1585 \mathrm{CE}$ on the site of an ancient church likely founded by St. Gaudioso in the fifth century CE. From this viewpoint, various features that are outlined below can be recognised.

\section{Astroni volcano}

Astroni volcano has an elliptically shaped ( 2 by $1 \mathrm{~km}$ ), EW elongated, vent (Fig. 5a). It has been the source of seven known eruptions (Isaia et al. 2004). The eruption units are separated by either thin palaeosols or erosional unconformities, which suggest repose periods of tens of years. They are composed of pyroclastic deposits generated by phreatomagmatic and subordinate magmatic explosions. The Astroni 5 and 7 eruption deposits include products of late low-energy explosions and lava extrusions and formed the Caprara and Rotondella lava domes, respectively. The Astroni 6 unit includes a subplinian fallout deposit, which was dispersed to the East and was recently recognised at Punta Campanella (M. di Vito, unpublished data). Thin ash deposits of almost all units are widely distributed in the Campania Plain intercalated with thin palaeosols containing traces of human settlements and land use (such as roads and ploughed fields).

\section{Solfatara}

Solfatara is the most well known volcanic edifice within the CF caldera (Fig. 4). This tuff cone is a located about $2 \mathrm{~km}$ NE of the town of Pozzuoli (Di Vito et al. 1999; Isaia et al. 2009). It was formed at $\sim 4.2 \mathrm{ka}$ (Smith et al. 2011) during the third epoch of volcanic activity (Di Vito et al. 1999) and was contemporaneous with the Averno 2 eruption in the western sector of the caldera (Isaia et al. 2009). Its crater is a $0.5 \times 0.6 \mathrm{~km}$ sub-rectangular depression, and the geometry of it is controlled by N40-50 W and N50E trending fault systems. These systems crosscut the area and have been active many times, before and after the formation of the crater, likely reactivating pre-existing regional structures during the volcano-tectonic events in the CF caldera (Orsi et al. 1996, 1999; de Vita et al. 1999). The Solfatara eruption vent migrated along a structurally controlled fissure and generated a complex eruption sequence that includes the S. Maria delle Grazie tephra, Mt. Olibano Lavas and tephra, the Accademia Lava Dome and the Solfatara Tephra (Isaia et al., 2009). Evidence for vent migration has also been observed in the deposits of other CF eruptions (Rosi and Sbrana 1987; de Vita et al. 1999; Isaia et al. 2004, 2009; Orsi et al. 2009; Tonarini et al. 2009; Di Vito et al. 2010).

Diffuse degassing is observed across the entire Solfatara crater (Chiodini et al. 2001), with fumarolic activity concentrated in the SE (Bocca Grande and Bocca Nuova area) and NE (Stufe) areas at the intersection between NW-SE and NE-S trending faults that intersect in the crater. The central part of the Solfatara crater is occupied by the Fangaia mud pool, at which the water-table emerges and the continuously rising hydrothermal fluids generate diffuse bubbling. The heat flux and fumarolic activity is relatively inactive in the NW sector of the crater, where the volcano's inner slopes and crater floor are vegetated. Solfatara was also the site of the first temperature geothermal measurements carried out by Breislak, De Luca, Aguilar, Mercalli, Bassani and Signore in 1791, 1872, 1904, 1907-1910, 1913 and 1921, respectively. The area within the crater is presently closed to the public as there was a fatal accident in 2017, when multiple members of a family fell into a sinkhole and suffocated (https://www.bbc.com/ news/world-europe-41243134).

The Solfatara volcano is described in Strabo (Strabonis Geographica) as the site of the God Vulcan. The site has been important through time as it was a source of rock alum and hydrothermal minerals to produce paint and other materials useful industrial processes. Lava blocks from quarries (Cava Regia) south of the crater were used in the construction of the Napoli pier and of the colonnade of the church San Francesco di Paola that opens on Piazza Plebiscito (Naples). 


\section{The Agnano Plain}

The flat Agnano Plain has a NW-SE elongated polygonal shape (Fig. 3). Only a few metres above sea level, it is bordered by rectilinear features, except on the NW where the margin is covered by the SE flank of the more recent Astroni tuff ring. The rectilinear features are high-angle scarps trending NW-SE and NE-SW. Many of them include triangular facets that develop 50 to $70 \mathrm{~m}$ from the present plain. The structure was generated during volcano-tectonic collapse related to the $\sim 4.5 \mathrm{ka}$ Agnano-Monte Spina (AMS) eruption (de Vita et al. 1999). Isopach and isopleth maps of the AMS fallout deposits indicate the vent area was the Agnano Plain (de Vita et al. 1999). Along the boundaries and internal slopes, deposits of pre-AMS eruptions and remnants of their edifices are visible. Beginning from the north and in a clockwise direction, it is possible to recognise the Pigna San Nicola tephra, Monte Sant'Angelo tephra, Coste San Domenico tuff cones and the Monte Spina lava dome. Surrounding valleys are filled by thick sequences of the Agnano Monte Spina tephra, especially the PDC and breccia deposits.

The Agnano Plain is the locus of intense hydrothermal activity. The Agnano thermae has remains of Roman thermal buildings that is evidence for this activity even in Roman times. The area is very active today with intense $\mathrm{CO}_{2}$ emission saturating the Grotta del Cane, a tunnel located along the Agnano's southern slopes. In addition, hydrothermal activity at Pisciarelli on the eastern slope of Solfatara has recently increased dramatically (Tamburello et al. 2019) with gas emission, a mud pool and an intermittent geyser. This activity is continuously monitored by the Istituto Nazionale di Geofisica e Vulcanologia-Osservatorio Vesuviano (INGV-OV) through multiparameter stations. The Pozzuoli Municipality issued an ordinance a few years ago to limit access to this dangerous site.

After the Roman period, the southern part of the plain subsided and a shallow, perennial lake developed, which drove progressive abandonment of the area. However, in $1870 \mathrm{CE}$, after a law was passed in $1865 \mathrm{CE}$, a project to drain the lake started. It created channels and a tunnel (still active today) to allow the water to drain to the sea. The lake completely dried up in 1871 and the Agnano thermae was constructed between 1909 and 1911.

\section{Gauro volcano}

The centre of the CF caldera is dominated by the Gauro volcano that formed between approximately 12 and $14 \mathrm{ka}$ (Di Renzo et al. 2011). It is the highest and largest tuff cone (Fig. 4) with a volume of about $0.5 \mathrm{~km}^{3} \mathrm{DRE}$ and formed of zeolitised yellow tuff. The base is only exposed in a few areas north of the volcano where it overlies the NYT. The rim of the cone is well preserved in its northern and southern sectors and named Monte Sant'Angelo alla Corvara (308 m asl) and Monte Barbaro (331 m asl), respectively. Its crater, Campiglione, is $750 \mathrm{~m}$ in diameter and can be accessed from the eastern flanks of the volcano via Campana, an important Roman road with well-preserved necropolis (Celle) and mausoleum. Since it is one of the first eruptions following the NYT, the cone is covered by thick sequence of pyroclastics associated with many of the more recent CF eruptions (Di Vito et al. 1999). The edifice has been subjected to intense deformation, and numerous NE and NW trending fault scarps and fault lines are evident. The top of Monte Sant'Angelo hosts a church dedicated to San Michele Arcangelo.

\section{Monte Nuovo}

The Monte Nuovo cone was generated during the most recent $\mathrm{CF}$ eruption (Fig. 5b), which was fed by multiple vents aligned along a NS trending fissure. It is $133 \mathrm{~m}$ high and the main (MV) crater is $420 \mathrm{~m}$ in diameter. This crater is visible after a short climb along the SE slopes of the cone. The southern vent (SV) is a semi-circular depression partially modified by the recent urbanisation that can be seen from the road to the entrance to the Monte Nuovo Oasis (Fig. 5b). Along the same road, and soon after the entrance, the products of this vent are exposed. They comprise fine to coarse ash beds, with large pumice fragments, that are overlain by several metres of coarse dark scoria. The road extends to the MV and runs along the crater rim. From this road, it is possible to see the Averno and Lucrino lakes, the Toiano depression, the Gulf of Pozzuoli and the La Starza marine terrace that hosts the town of Pozzuoli. The cone completely modified the morphology of the area, closing the southern part of Lake Averno and reducing the size of Lake Lucrino. Furthermore, it buried the Tripergole thermal village and covered the Roman harbour structures and roads in pyroclastic material. Numerous other buildings and infrastructure were damaged by the deformation and earthquakes preceding and accompanying the eruption.

\section{Lake Averno}

Lake Averno is located in the western part of CF and occupies the crater of the Averno eruption (Fig. 4). The lake was of major importance to the Romans, who considered it to be the entrance to Hades, and Avernus was a synonym for the underworld (in Vergilius Aeneid, Aeneas descends to the underworld through a cave near the lake). The lake is $0.5 \mathrm{~km}^{2}$ and from a hydrogeological point of view it represents the extension of the water table-it is fed by a direct meteoric water supply and drained towards the sea by an $\sim 1 \mathrm{~km}$ long canal. The products of the 4.1-4.3 ka Averno 2 eruption are 
preserved along the crater walls, which include a sequence of fallout deposits (coarse pumice beds) followed by an ash deposit that is several metres in thickness (details in Di Vito et al. 2011). This sequence overlays the 5.0-5.4 ka Averno 1 deposit, one of the first eruptions of the third epoch of the $\mathrm{CF}$ activity and the mature palaeosol B. This mature palaeosol appears as a dark-brown horizon formed during the long quiescence between the second and third epochs and it overlies other distal tephra and the yellow tuff of the large Archiaverno tuff ring that are well exposed on the western crater walls. This tuff represents the bedrock of the entire Averno area and has been excavated during the construction of two Roman tunnels: the Grotta della Sibilla and the Grotta di Cocceio. The latter is a $1 \mathrm{~km}$ long tunnel with vertical openings for air circulation and an aqueduct connecting the lake and the Cuma acropolis. The Apollo Temple, a building that made use of the thermal springs on the eastern shore of the lake (Fig. 4), is one of the numerous Roman buildings that were covered by Monte Nuovo products.

\section{Capo Miseno}

The Capo Miseno tuff cone is one of the youngest volcanic edifices of the caldera and located on the western side of CF (Fig. 4). It is $164 \mathrm{~m}$ high and is almost completely composed of yellow tuff. Only one third of the edifice is preserved in its northern part and includes the outer slopes and part of the crater, hosting a lighthouse (Fig. 4). Capo Miseno has one of the best views of Vesuvius, the Sorrento Peninsula and Capri. The area was important in Roman times hosting the harbour and many structures related to the presence of the Roman fleet, like the termination of the Augustan Aqueduct (Piscina Mirabilis). The site is also where the famous description of the 79 CE Pompeii eruption of Vesuvius was made. The details were recounted by Pliny the Younger in his letters to Tacitus many years after the eruption, and he explained that his uncle Pliny the Elder had departed from Capo Miseno with his fleet to go to the slopes of Vesuvius and help the people.

\section{Cuma}

Cuma is the site of the first Greek polis (i.e. city) in the western Mediterranean area ( 750 BCE) and was founded by colonists from the island of Euboea, approximately coeval with the settlement of Pithecusae on Ischia (NW side), the first Greek emporion (port of trade) in the western Mediterranean. The site is located on a small lava dome and faces to the Tyrrhenian Sea (Fig. 8), with the position being important for both commercial and military purposes. It sits just outside of the western boundary of the CF caldera. The lava dome is overlain by a sequence of a fallout deposits comprised of white pumice and scoria fragments, a palaeosol and a thick deposit including a basal layer of spatter agglutinate and a breccia that was correlated by Rosi and Sbrana (1987) to the Campanian Ignimbrite eruption. The sequence is unconformably overlain by both facies of the NYT. The famous Antro della Sibilla (Cavern of Sibilla; Fig. 7), one of antiquity's most important sanctuaries, and other acropolis structures were excavated from the yellow NYT tuff at this site.

\section{Thermal baths}

The Roman baths of the Phlegraean Fields exploited the natural volcanic thermal waters and fumaroles. It is the first region known to use the geothermal sources for heating. In fact, thermal baths had heated floors (hypocaustum) that used an ingenious system of long shafts to capture the hot vapours from the geothermal system, which was invented in Baia-probably by Sergius Orata at the end of second century BCE (Plinius, Nat. Hist. IX, LXXIX, 168).

Baia became the largest Phlegraean thermal bath centre and the largest in the ancient world. It included magnificent bath complexes and large Roman villas (Fig. 9). Baia brought together the abundant and diverse healthy waters, which provided the right therapeutic indications and contraindications. In the last century of the Republic, at the time of Augustus, Baia underwent great urban development and thermal baths and grandiose buildings were built, which Strabo $(\mathrm{V}, 4,7)$ stated was not inferior to Puteoli. The settlement expanded into the sea to make the most of the thermal resources, using innovative engineering techniques and the intensive use of pozzolana. The growing demand for building by the Roman nobility was noted by the poet Quintus Horatius Flaccus: "You insist on extending the beach even in the midst of the rumbling sea of Baia not yet happy with your possessions on the Ripa" (Horatius Carmina, book II, 18). Lucius Annaeus Seneca later addressed the same criticism: "Wherever springs of thermal waters spring, new luxurious hotels will rise there. Wherever the lido curves into an inlet, you will lay new foundations, and, not content with the dry land, you will also build on the artificial soil that you have taken from the sea" (Seneca letters, 89). This invasive urban project to exploit the marine thermal spring also involved the construction of an artificial island off the bay, in the Fumose area, that was financed by Marcus Licinius Crassus Frugi. It is this environmental context that makes Horace say, "in the world there is no more beautiful gulf than that of Baia" (Epist. I, 1, 83). Caesar in the Late Republican Age, and afterwards Augustus, Nero, Claudius, Hadrian, Alexander Severus and other emperors made use of them. The ancient writers testify to the grandeur of the Baths of Baia, so to do the imposing remains of the so-called temples of Mercury, Diana and Venus in Baia and the majestic 
temples of Neptune, Aesculapius and Diana near the Flavian Amphitheater in Pozzuoli.

In addition to the public baths, there were also splendid private baths in the imperial and patrician villas. It is probable that the famous Stoves of Tritoli or Nero, between Baia and Lucrino, were part of the magnificent villa that Nero had built there, whose facade resembled that of the domus aurea. There are reports of five imperial villas in Baia. In Baia, under the pretext of thermal and marine treatment, the richest and most aristocratic of Roman society arrived during the summer, immersing themselves in a life of luxury and pleasure. It is easy to imagine what fascination the beauties and delights of those places must have exerted on writers, poets and artists. Propertius (Lib I, Eleg. XI), Martial (Epig. LXIII), Cicero (Epist. Mor., Lib. V) and Seneca (Epist. LI) describe its luxury and corruption. The most important thermal baths of Baia were those on the slope of the hill, amid famous myrtle groves (Celsus II, 17). The first historical information about these Phlegraean thermal springs dates to the second century BCE and it is provided by Livius who commented that in $176 \mathrm{BCE}$ the consul Gnaeus Cornelius went to the baths of Baia for the treatment of his illness. Varo, Strabo and Pliny attested to the ancient fame of the thermal waters in the Phlegraean region (see also Fig. 12). Pliny wrote that the waters contributed to the foundation of Pozzuoli, adding that "nowhere more than in the bay area is there a greater quantity of mineral waters to provide various remedies" (Pliny, Nat. Hist., XXXI, 2).
In some cases, thermal baths consisted also of rooms that were excavated directly into the tuff; the fumaroles in the centre of the hill gave rise to the highest temperatures and these were reserved for rooms called the sweats. Other rooms were heated by the hot gases that were conveyed through long ducts under the floor. In the rooms beneath, the thermal waters gushed out and these were used for a bath following sweating. Vast complexes of separate rooms were built in masonry, which enormously expanded the baths. These extensions were indispensable to satisfy the growing clientele and the aesthetic taste of the famous and wealthy visitors.

Away from Baia, there were baths in other CF localities that had similar thermal qualities. On the site where Monte Nuovo now stands was the mediaeval village of Tripergole, of which Ferrante Loffredo (1580) wrote: "There was still an ancient Truglio not already of the grandeur of those of Baia, but it was of beautiful architecture, and very well done". At this same location was the famous villa "Academia" of Cicero, where shortly after the death of the orator, hot springs appeared, which the new owner Antistius Vetus called Aquae Ciceronianae. It proved to be very effective in relieving eye diseases. For the appearance of these medicinal waters, Tullius Laurea, Cicero's freedman, dictated an epigraph, which could be read in the villa, and of which Pliny (Nat. Hist., XXXI, 2) transcribed the text. Among the various buildings that arose on the shores of Lake Avernus, after the work done by Agrippa, was a majestic thermal site on the
Fig. 12 a Front of a large sarcophagus (about $2 \mathrm{~m}$ length and $1 \mathrm{~m}$ width) that has been dated to 250-260 CE, illustrating the port of a thriving city on the sea. It is identifiable as Puteoli with the Ripa puteolana: dead people are depicted in the centre, whereas various buildings appear in the background, including the Caligolian pier, the temple of Augustus and the amphitheatre. Courtesy of the Vatican Museums, Cortile Ottagono PE 4. Front of sarcophagus (inv. N. 973). b Drawings of glass flasks from the Puteoli series, of uncertain provenance from the third to fourth century CE. Graphic reproduction of Ripa puteolana and Port Iulius buildings, National Museum, Prague
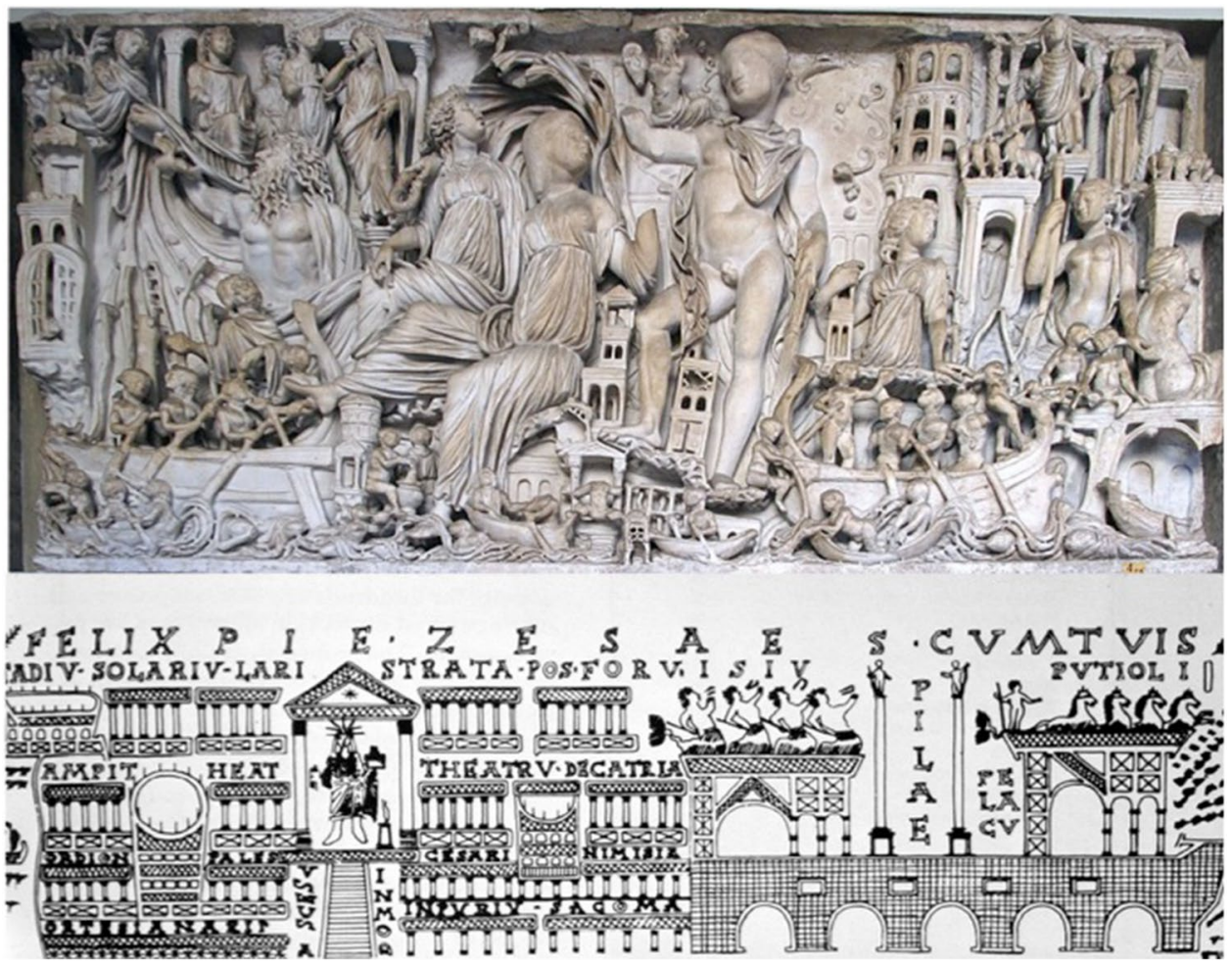
east bank that is now represented by the Temple of Apollo. Until the eighteenth century, a thermal spring was used here, called Acqua di Capone, which seems to correspond to the mediaeval Balneum De Ferris.

Puteoli also had remarkable thermal baths, including the Temple of Diana. On the Leucogei Hills (Fig. 3), locations between the Solfatara and Agnano, there were numerous hot springs that likely correspond to the Fontes Araxi of the Romans. There were the grandiose Roman baths of Agnano that extended for over $400 \mathrm{~m}$ around the Monte Spina, where there are still the ruins today. Strabo $(\mathrm{V}, 4,7)$ undoubtedly alludes to the Baths of Bagnoli, Pisciarelli (Bagno della Bolla during the Middle Ages; Fig. 13), referring to Neapolitan thermal waters (until the time of Augustus, the territory of Neapolis reached and included the Leucogei Hills), which he says were not inferior to those of Baia, if not for the number.

During the early Middle Ages, despite the invasions of the barbarians and the ground subsidence, the famous thermal baths maintained the importance of CF as they were appreciated by barbarian kings and wealthy people of the time. In the sixth century, Cassiodorus refers to Athalaric king of the Ostrogoths that "Nothing is more sublime than

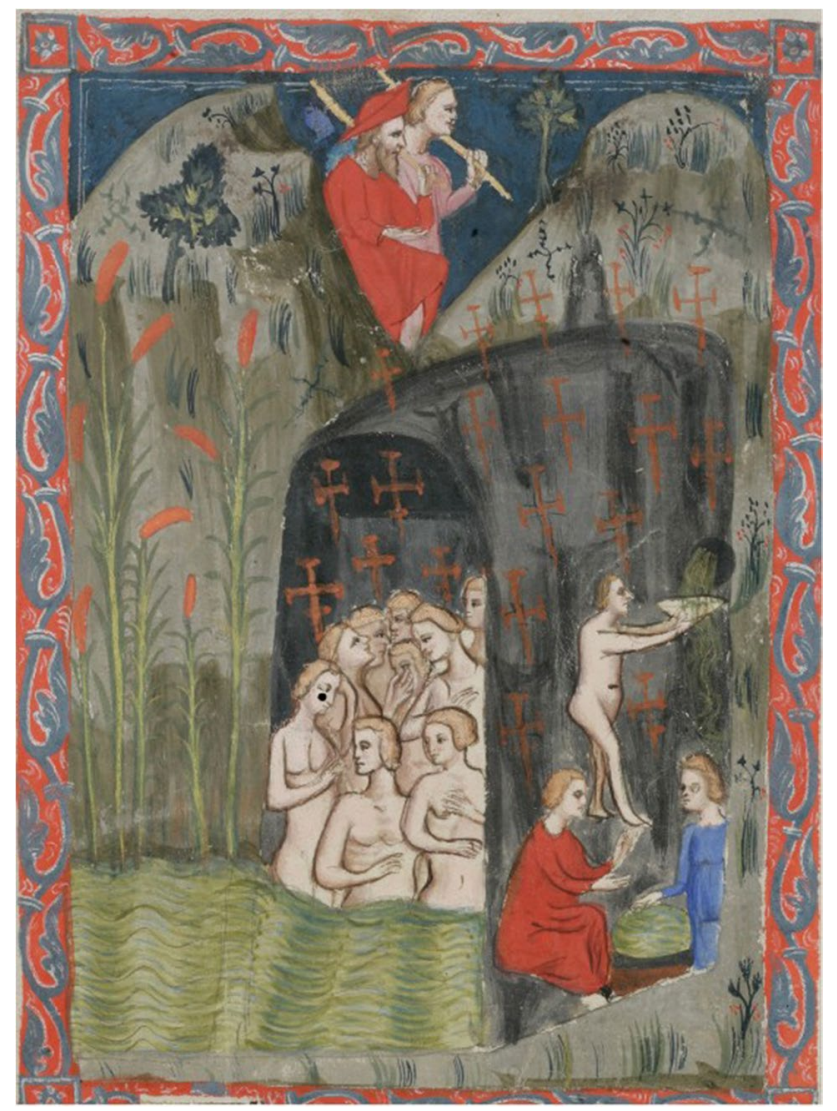

Fig. 13 The Bolla of Baths of Pozzuoli. Cologny, Fondation Martin Bodmer, Cod. Bodmer 135, f. 4r - [Peter of Eboli], http://www.ecodices.ch/en/fmb/cb-0135/4r/0 by Pietro Fabris the shores of Baia, which combines the possibility of having very sweet delights and of being satisfied with the incomparable gift of health" (Variae, IX, epist. 6). In the year 866 $\mathrm{CE}$, the emperor Ludovicus II, after having occupied Capua, visited Pozzuoli to enjoy its thermal baths. In his Itinerarium, Rabbi Benjamin of Tudela, who went from Spain to Italy in $1161 \mathrm{CE}$, mentions the healing virtues of the thermal waters of Pozzuoli. Among the many magical works attributed to Virgil by the Neapolitan people in the Middle Ages, are that he built the baths of Baia for the benefit of the Neapolitan people, indicating the different diseases could be healed without the need for doctors.

The Puteolan thermal baths enjoyed great fame in the thirteenth century as they attracted the interest of emperor Frederick II of Swabia as documented by chronicler Riccardo from S. Germano. They were also featured in a Latin poem titled De balneis Terrae Laboris, written between 1212 and $1221 \mathrm{CE}$ by Pietro da Eboli and dedicated to the emperor Frederick II, or perhaps to his father. The baths attracted numerous sick people to enjoy their admirable effectiveness. In one of the first documents of Neapolitan art and culture of the fourteenth century, Pietro d'Eboli in a Latin poem with the title of Bagni di Pozzuoli described thirty-one baths, many of which are inside the ancient Roman thermal ruins. In the fifteenth century and on the beach facing the Serapeum, the bath of Fontana was active for bathing treatments only. This source later became completely submerged by the sea with the remains of the Macellum (so-called Serapeum), from which only the ends of three columns emerged, were used for mooring ships. This spring of thermal water was brought to light once again during the ascending bradyseism pre-Monte Nuovo.

Charles II of Anjou founded the Holy Spirit hospital in Tripergole, located between Baia and Puteoli and near Lucrino, by decree on 15 September 1298. This well-furnished hospital for the poor had one hundred beds and contributed to the rebirth of Baia. Tripergole became a populous village with elegant buildings and restaurants and sumptuous villas for the knights who had money to spend. The revival of Baia and its thermal baths was remembered and celebrated by Petrarch, Boccaccio, Sannazaro, Cariteo and, above all, by Pontano in his poem titled Hendecasyllaborum seu Bajarum libri. There are numerous testimonies of the fame that the baths of Pozzuoli enjoyed in the fourteenth and fifteenth centuries. Pope Boniface IX (1389-1404) came to use it, and it is widely mentioned in studies (such as Bracciolini, Aretino), travel diaries and itineraries of the time. It appears that there was continuous thermal balneotherapy in the region between Roman times and the Monte Nuovo eruption (Giacomelli and Scandone 2012).

The eruption of Arso in $1302 \mathrm{CE}$ on Ischia damaged the known thermal baths on the island, which date back to at least the thirteenth century (Cronaca di Parthenope), and the 
violent earthquakes and eruption of Monte Nuovo destroyed Tripergole and damaged the remaining Phlegraean baths. Simone Porzio commented after the eruption: "Those baths celebrated for so many centuries, which gave health to so many sick people, lie buried in ash". The Subveni Homini (or Gerolomini) thermal complex, not destroyed by the eruption of $1538 \mathrm{CE}$, remained for a long time the main, if not the only one, in Pozzuoli. It was located in a cave dug at the foot of Mount Olibano. It was partially buried by ash of Monte Nuovo but the Viceroy Don Pedro of Toledo restored it and put it back into operation in $1540 \mathrm{CE}$ (Di Bonito 2002). Moreover, to help the rebirth of Pozzuoli, that was largely in ruins, Pedro of Toledo built a splendid villa there, inviting and exhorting the Neapolitan patricians to visit. His efforts brought new life to Pozzuoli in the years following the eruption, and the baths resumed and generated renewed fortune. Another Spanish Viceroy, Don Pedro Antonio of Aragon, assigned Sebastiano Bartolo, one of the Neapolitan primary doctors of the time, to write the Thermologia Aragonia (1679) that described the thermal baths of the entire Phlegraean region, from Bagnoli to Baia, and documented his scientific studies into their curative efficacies. He documented the thermal baths in existence before the eruption of Monte Nuovo in three epigraphs (two still surviving) located in Naples, Pozzuoli and Baia (Giacomelli and Scandone 2012, Scandone and Giacomelli 2019).

The thermal baths were a central element in Roman life and inextricably linked to Baia and to CF. They also contributed to the literary fortune that $\mathrm{CF}$ had in Classical Antiquity. The location of $\mathrm{CF}$, in the centre of the ancient Mediterranean routes, was of course key but the mystical and magical atmosphere associated with the region was particularly unique and attractive.

\section{The Archaeological Museum in Baia and the Archaeological Park of Campi Flegrei}

The archaeological record detailed above in the Phlegraean area and on the Campanian Plain is now only partially exposed. Some of the limited finds associated with the prehistoric phases are exhibited in the Prehistoric Collection of the National Archaeological Museum of Naples (MANN). A large portion of the finds from the Greek and Roman age are housed in the Archaeological Museum of the Campi Flegrei in the Aragonese Castle in Baia (https:// www.beniculturali.it/luogo/parco-archeologico-dei-campiflegrei-museo-archeologico-dei-campi-flegrei-nel-castellodi-baia), which opened in its current form in 2010. These objects are exhibited chronologically in the Aragonese Castle, which was built on the site of a Roman villa. This museum also highlights the effect of the volcanic activity on the people that inhabited the area. It details the impact of bradyseism on human settlements, based on the record from the Nymphaeum of Punta Epitaffio in Baia and the Sacello degli Augustali in Miseno.

Many of the sites that provided insight into the history of CF are included in the Archaeological Park of Campi Flegrei (https://www.beniculturali.it/ente/parco-archeologi co-dei-campi-flegrei). It was founded to protect and make many of the sites mentioned above accessible, such as Cuma, the Roman Baths of Baia, Amphitheater Flavio, Temple of Serapis, Stadium of Antonino Pio, the monuments of Miseno and Bacoli, which include the Roman Theater of Miseno, the Dragonara, the Sacello degli Augustali, the necropolis of Cappella, Piscina Mirabile, Cento Camerelle, and the Tomb of Agrippina. These sites and the museums are important records of the rich cultural heritage of this incredibly active volcanic region, and they document how people lived with and exploited the changing landscape.

\section{Conclusions}

This overview provides insights into the extraordinary history of the Campania region where humans have cohabited with volcanoes and related earth system processes [e.g. hot thermal fumaroles and waters, earthquakes, positive and negative bradyseism (i.e. ground inflation and ground subsidence), sea level rise and fall] for numerous millennia. Campi Flegrei volcano has developed over hundreds of thousands of years and periodically has drastically changed the landscape. This volcanic activity has provided novel resources (such as pozzolana or pulvis puteolana mortar) for the people that chose to occupy the region. The archaeological evidence suggests that occupation of Campania was continuous for the last 10,000 years, although some areas were certainly abandoned for significant periods while the landscape recovered from significant ash fallout associated with eruptions from $\mathrm{CF}$ and Vesuvius. Written records document the development of Pozzuoli and other Phlegraean towns, and the infrastructure that was installed to enable travel to the wondrous thermal baths. The volcanic history and activity in the region have been reconstructed via geological investigations but the archaeological and written records provide specific details. They record the bradyseism in Pozzuoli and the surrounding area, the precursors to the 1538 CE Monte Nuovo eruption, and provide a comprehensive account of the vent locations, style of activity and timing of the Monte Nuovo eruption phases. This combination of knowledge acquired from geological, archaeological, historical and anthropological research has allowed us to highlight some of the key interactions between humans and the active volcanic environment between around $10 \mathrm{ka}$ and $1538 \mathrm{CE}$. The incredible geoheritage of the Phlegraean area is unequivocally demonstrated by the imposing vents and deposits generated by the wide range of volcanic activity there, 
detailed archaeological sites, impressive historical buildings and in the written records that span thousands of years. With this compilation, we have tried to illustrate Campania's interwoven, rich and protracted human and volcanological history to document the ongoing multi-millennial relationship between people and the volcanic forces and resources in and around Campi Flegrei. The volcanic legacy and the geoarchaeological heritage within CF preserved in the park and museums are an educational trail that provides evidence of the infrequent, but catastrophic, volcanic eruptions and their impact.

Acknowledgements The authors warmly thank W. Rose for encouraging us to carry out this research and write this paper. We also thank the editor C. Gregg and two reviewers for their constructive suggestions and comments that improved the clarity of the manuscript.

Open Access This article is licensed under a Creative Commons Attribution 4.0 International License, which permits use, sharing, adaptation, distribution and reproduction in any medium or format, as long as you give appropriate credit to the original author(s) and the source, provide a link to the Creative Commons licence, and indicate if changes were made. The images or other third party material in this article are included in the article's Creative Commons licence, unless indicated otherwise in a credit line to the material. If material is not included in the article's Creative Commons licence and your intended use is not permitted by statutory regulation or exceeds the permitted use, you will need to obtain permission directly from the copyright holder. To view a copy of this licence, visit http://creativecommons.org/licenses/by/4.0/.

\section{References}

Accorsi AC, Aiello E, Bartolini C, Castelletti L, Rodolfi G, Ronchitelli A (1979) Il giacimento Paleolitico di Serino (Avellino): stratigrafia ambienti e paletnologia, Atti della Società Toscana di Scienze Naturali - Memorie Serie A LXXXVI 1979, 435-487

Adam J-P (1988) L'arte di costruire presso i Romani, Milano

Albert PG, et al (2015) Revisiting the Y-3 tephro- stratigraphic marker: A new diagnostic glass geochemistry, age estimate, and details on its climatostratigraphical context: Quaternary Sci- ence Reviews 118:105-121. https://doi.org/10.1016/j.quascirev.2014.04.002

Albert PG, Giaccio B, Isaia R, Costa A, Niespolo EM, Nomade S, Pereira A, Renne PR, Hinchliffe A, Mark DF, Brown RJ, Smith VC (2019) Evidence for a large-magnitude eruption from Campi Flegrei caldera (Italy) at 29 ka. Geology:1-5.https://doi.org/10. $1130 / g 45805.1$

Albore Livadie C (1986) Considérations sur l'homme préhistorique et son environnement dans le territoire phlégréen, in Tremblements de terre, éruptions volcaniques et vie des hommes dans la campanie antique, Napoli, 189-205, pl. LXXXVIII-XCIX

Annecchino R (1960) Storia di Pozzuoli e della zona flegrea. Conte ed., Pozzuoli

Barberi F, Innocenti F, Lirer L, Munno R, Pescatore T, Santacroce R (1978) The Campanian Ignimbrite: a major prehistoric eruption in the Neapolitan area (Italy). Bull Volcanol 41:10-31

Barberi F, Macedonio G, Pareschi M, Santacroce R (1990) Mapping the tephra falloutrisk: an example from Vesuvius (Italy). Nature 344:142-144

Brown RJ, Orsi G, de Vita S (2008) New insights into Late Pleistocene explosive volcanic activity and caldera formation on Ischia (southern Italy). Bull Volcanol. 70(5):583-603
Bourne AJ, Albert PG, Matthews IP, Trincardi F, Wulf S, Asioli A, Blockley SPE, Keller J, Lowe JJ (2015) Tephrochronology of core PRAD 1-2 from the Adriatic Sea: insights into Italian explosive volcanism for the period 200-80 ka, Quaternary Science Reviews, Volume 116:28-43. https://doi.org/10.1016/j.quascirev. 2015.03.006

Bourne AJ, Lowe JJ, Trincardi F, Asioli A, Blockley SPE, Wulf S, Matthews IP, Piva A, Vigliotti L (2010) Distal tephra record for the last ca 105,000 years from core PRAD 1-2 in the central Adriatic Sea: implications for marine tephrostratigraphy. Quat Sci Rev 29:3079-3094. https://doi.org/10.1016/j.quascirev.2010.07.021

Buchner G (1986) Eruzioni vulcaniche e fenomeni vulcano-tettonici di età preistorica e storica nell'isola d'Ischia, in Tremblements de terre, éruptions volcaniques et vie des hommes dans la campanie antique, Napoli, 145-188, pl. LXXXIV-LXXXVII

Chiodini G, Frondini F, Cardellini C, Granieri D, Marini L, Ventura G (2001) CO2 degassing and energy release at Solfatara volcano,Campi Flegrei, Italy. J Geophys Res 106:213-221

Cioni R, Longo A, Macedonio G, Santacroce R, Sbrana A, Sulpizio D, Andronico D (2003) Assessing pyroclastic fall hazard through field data and numericalsimulations: example from Vesuvius. J. Geophys. Res 108(B2):2063-2073

Costa A, Dell'Erba F, Di Vito MA, Isaia R, Macedonio G, Orsi G, Pfeiffer T (2009)Tephra fallout hazard assessment at the Campi Flegrei caldera (Italy). Bull Volcanol 71(3):259-73. https://doi. org/10.1007/s00445-008-0220-3

Costa A, Folch A, Macedonio G, Giaccio B, Isaia R, Smith VC (2012) Quantifying volcanic ash dispersal and impact of the Campanian Ignimbrite super-eruption. Geophys Res Lett 39.https://doi.org/10.1029/2012g1051605

De Astis G, Pappalardo L, Piochi M (2004) Procida volcanic history: new insights into the evolution of the Phlegraean Volcanic District (Campania region, Italy). Bull Volcanol 66:622-641. https://doi.org/10.1007/s00445-004-0345-y

De Criscio G (1895) I Campi Flegrei illustrati. Ed Antonio Pisano., 2012 ISBN: 9788895938158

de'Gennaro M, Cappelletti P, Langella A, Perrotta A, Scarpati C (2000) Genesis of zeolites in the Neapolitan Yellow Tuff: geological, volcanological and mineralogical evidence. Contrib Mineral Petrol 139:17-35

De Hollanda F (1541) Pozzuoli e il suo Golfo nel 1539, Codice Escorial fol. 52, De Pintura Antiga. Lisbon

de Tudela B (1270) Itinerarium ex versione Benedicti Ariae Montani, 1764, Lipsia

de Vita S, Di Vito MA, Gialanella C, Sansivero F (2013) The impact of the Ischia Porto Tephra eruption (Italy) on the Greek colony of Pithekoussai. Quat Int 303:142-152. https://doi.org/10. 1016/j.quaint.2013.01.002

de Vita S, Orsi G, Civetta L, Carandente A, D'Antonio M, Di Cesare T, Di Vito M, Fisher RV, Isaia R, Marotta E, Ort M, Pappalardo L, Piochi M, Southon J (1999) The Agnano-Monte Spina eruption $(4.1 \mathrm{ka})$ in the resurgent, nested Campi Flegrei caldera (Italy). J. Volcanol. Geotherm. Res 91(2-4):269-301

de Vita S, Sansivero F, Orsi G, Marotta E, Piochi M (2010) Volcanological and structural evolution of the Ischia resurgent caldera (Italy) over the past $10 \mathrm{ka}$. In: Groppelli G, Viereck L, editors. "Stratigraphy and geology in volcanic areas", GSA book series, Special paper n 464:193-239

De Vivo B, Rolandi G, Gans PB, Calvert A, Bohrson WA, Spera FJ, Belkin HE (2001) New constraints on the pyroclastic eruptive history of the Campanian volcanic plain (Italy). Mineral Petrol 73:47-65

Del Gaudio C, Aquino I, Ricciardi GP, Ricco C, Scandone R (2010) Unrest episodes at Campi Flegrei. A reconstruction of vertical ground movements during 1905-2009. J Volcanol Geotherm Res 195(1):48-56 
Delibrias G, Di Paola GM, Rosi M, Santacroce R (1979) La storia eruttiva del complesso vulcanico Somma-Vesuvio ricostruita dalle successioni piroclastiche del Monte Somma. Rend Soc It Mineral Petrol 35:411-438

Di Bonito R (2002) Pozzuoli. Uomini e vicende tra Medioevo ed età moderna. Ed. Adriano Gallina

Di Girolamo P, Ghiara MR, Lirer L, Munno R, Rolandi G, Stanzione A (1984) Vulcanologia e petrologia dei Campi Flegrei. Boll Soc Geol Ital 103:349-413

Di Napoli R, Aiuppa A, Sulli A, Caliro S, Chiodini G, Acocella V, Ciraolo G, Di Vito MA, Interbartolo F, Nasello C, Valenza M (2016) Hydrothermal fluid venting in the offshore sector of Campi Flegrei caldera: a geochemical, geophysical, and volcanological study. Geochem. Geophys. Geosyst., 17. https:// doi.org/10.1002/2016GC006494

Di Renzo V, Arienzo I, Civetta L, D'Antonio M, Tonarini S, Di Vito MA, Orsi G (2011) The magmatic feeding system of the Campi Flegrei caldera: architecture and temporal evolution. Chem Geol 281:227-241. https://doi.org/10.1016/j.chemgeo.2010.12.010

Di Renzo V, Di Vito MA, Arienzo I, Civetta L, D'Antonio M, Giordano F, Orsi G, Tonarini S (2007) Magmatic history of Somma-Vesuvius on the basis of new geochemical and isotopic data from a deep bore-hole (Camaldoli della Torre). J Petrol 48(4):753-784. https://doi.org/10.1093/petrology/eg1081

Di Vito MA, Acocella V, Aiello G, Barra D, Battaglia M, Carandente A, Del Gaudio C, de Vita S, Ricciardi GP, Ricco C, Scandone R, Terrasi F (2016) Magma transfer at Campi Flegrei caldera (Italy) before the 1538 AD eruption, Scientific Reports 6:32245: 1-9 . https://doi.org/10.1038/srep32245

Di Vito MA, Arienzo I, Braia G, Civetta L, D’Antonio M, Di Renzo V, Orsi G (2011) The Averno 2 fissure eruption: a recent small-size explosive event at the Campi Flegrei caldera (Italy). Bull. Volcanol 73:295-320. https://doi.org/10.1007/s00445-010-0417-0

Di Vito MA, Isaia R, Orsi G, Southon J, Vita SD, D’Antonio M, Pappalardo L, Piochi M (1999) Volcanism and deformation since 12,000 years at the Campi Flegrei caldera (Italy). J Volcanol Geotherm Res 91:221-246

Di Vito MA, Sulpizio R, Zanchetta G, D’Orazio M (2008) The late Pleistocene pyroclastic deposits of the Campanian Plain: new insights into the explosive activity of Neapolitan volcanoes. J Volcanol Geotherm Res 177:19-48. https://doi.org/10.1016/j. jvolgeores.2007.11.019

Di Vito MA, Castaldo N, de Vita S, Bishop J, Vecchio G (2013) Human colonization and volcanic activity in the eastern Campania Plain (Italy) between the Eneolithic and Late Roman periods. Quat Int 303:132-141. https://doi.org/10.1016/j.quaint.2013.01.001

Di Vito MA, Talamo P, de Vita S, Rucco I, Zanchetta G, Cesarano M (2019) Dynamics and effects of the Vesuvius Pomici di Avellino Plinian eruption and related phenomena on the Bronze Age landscape of Campania region (Southern Italy). Quat Int 499(B):231-244. https://doi.org/10.1016/j.quaint.2018.03.021

Di Vito MA, Zanella E, Gurioli L, Lanza R, Sulpizio R, Bishop J, Tema E, Boenzi G, Laforgia E (2009) The Afragola settlement near Vesuvius, Italy: the destruction and abandonment of a Bronze Age village revealed by archaeology, volcanology and rock-magnetism. Earth Planet. Sci. Lett 277:408-421. https://doi.org/10. 1016/j.epsl.2008.11.006

Erfurt-Cooper P (2011) Geotourism in volcanic and geothermal environments: playing with fire? Geoheritage 3:187-193. https://doi. org/10.1007/s12371-010-0025-6

Frederiksen M (1977) Una fonte trascurata sul bradisismo puteolano, in: I Campi Flegrei nell'archeologia e nella storia. Atti del Convegno Internazionale, 4-7 Maggio 1976, Roma

Fugazzola Delfino MA, Salerno A, Tagliacozzo A, Tinè V, Vanzetti A (2003) Una comunità della facies di Laterza nella pianura campana: L'area "Forum" di Gricignano -US Navy (CE), Atti XXXV Riunione Scientifica IIPP, Firenze, pp. 199-214

Garufi CA (1937) Riccardo di San Germano Chronica, ed. in RIS 2, VII/2, Bologna 1937-1938, pp. 146-161 (traduzione di Stefano Savone e Germana Villetti)

Giaccio B, Isaia R, Fedele FG, Canzio ED, Hoffecker J, Ronchitelli A, Sinitsyn AA, Anikovich M, Lisitsyn SN, Popov VV (2008) The Campanian Ignimbrite and Codola tephra layers: two temporal/ stratigraphic markers for the Early Upper Palaeolithic in southern Italy and eastern Europe. J Volcanol Geotherm Res 177:208-226. https://doi.org/10.1016/j.jvolgeores.2007.10.007

Giaccio B, Niespolo EM, Pereira A, Nomade S, Renne PR, Albert PG, Arienzo I, Regattieri E, Wagner B, Zanchetta G, Gaeta M, Galli P, Mannella G, Peronace E, Sottili G, Florindo F, Leicher N, Marra F, Tomlinson EL (2017b) First integrated tephrochronological record for the last $190 \mathrm{kyr}$ from the Fucino Quaternary lacustrine succession, central Italy. Quat Sci Rev 158:211-234. https://doi.org/10.1016/j.quascirev.2017.01.004

Giaccio B, Hajdas I, Isaia R, Deino A, Nomade S (2017a) High-precision $14 \mathrm{C}$ and $40 \mathrm{Ar} / 39 \mathrm{Ar}$ dating of the Campanian Ignimbrite (Y-5) reconciles the time-scales of climatic-cultural processes at 40 ka. Sci Rep:1-10.https://doi.org/10.1038/srep45940

Giacomelli L, Scandone R (2012) History of the exploitation of thermo-mineral resources in Campi Flegrei and Ischia, Italy. J Volcanol Geotherm Res 209-210:19-32

Giamminelli R (1996) Edilizia e urbanistica di Pozzuoli dal X alla metà del XVII secolo dai documenti iconografici: Bollettino Flegreo, v. 3

Giampaola D, Boenzi G (2013) Interazione tra attività vulcanica e vita dell'uomo: evidenze archeologiche nell'area di Napoli. Miscellanea INGV 18:38-44

Gurioli L, Pareschi MT, Zanella E, Lanza R, Deluca E, Bisson M (2005) Interaction of pyroclastic currents with human settlements: evidences from ancient Pompeii. Geology 33:441-444

Isaia R, D'Antonio M, Dell'Erba F, Di Vito M, Orsi G (2004) The Astroni volcano: the only example of close eruptions within the same vent area during the recent history of of the Campi Flegrei caldera (Italy), J. Volcanol. Geotherm. Res 133:171-192

Isaia R, Marianelli P, Sbrana A (2009) Caldera unrest prior to intense volcanism in Campi Flegrei (Italy) at $4.0 \mathrm{ka}$ B.P.:implications for caldera dynamics and future eruptive scenarios. Geophys Res Lett 36:L21303. https://doi.org/10.1029/2009GL040513

Jacono L (1942) Il Serapeo di Pozzuoli, Relazione all'Accademia di archeologia, lettere e belle arti. Napoli

Jamsilla N (1258) De rebus gestis Friderici II imperatoris eiusque filiorum Conradi et Manfredi Apuliae et Siciliae regum, in Del Re, Cronisti e scrittori, 1868, Napoli

Jannelli L (1999) La frequentazione dell'acropoli di Cuma in età PreProtostorica - i dati dello scavo Buchner. Annali Di Archeologia e Storia Antica 6(1999):73-90

Laforgia E, Boenzi G, Sgherzi BM (2007a) Caivano-Afragola (Napoli). Insediamenti tra neolitico ed eneolitico, in Strategie d'insediamento fra Lazio e Campania in età preistorica e protostorica, Atti della XL Riunione Scientifica dell'I.I.P.P. (Roma, Napoli, Pompei 2005), Firenze, pp. 619-622

Laforgia E, Boenzi G, Viscione M (2007b) Un insediamento dell'eneolitico finale a Carinaro: dati preliminari dagli scavi condotti all'interno del Polo Calzaturiero, in Strategie d'insediamento fra Lazio e Campania in età preistorica e protostorica, Atti della XL Riunione Scientifica dell'I.I.P.P. (Roma, Napoli, Pompei 2005), Firenze, pp. -623-626

Lane CS, Brauer A, Martín-Puertas C, Blockley SPE, Smith VC, Tomlinson EL (2015) The Late Quaternary tephrostratigraphy of annually laminated sediments from Meerfelder Maar, 
Germany. Quat Sci Rev 122:192-206. https://doi.org/10. 1016/j.quascirev.2015.05.025

Lirer L, Munno R (1975) Il Tufo Giallo Napoletano (Campi Flegrei). Period Mineral 44:103-118

Lirer L, Luongo G, Scandone R (1987) On the volcanological evolution of Campi Flegrei. Eos Trans AGU 68(16):226-234. https://doi.org/10.1029/EO068i016p00226

Loffredo F (1580) Le antichità di Pozzuoli e luoghi convicini, Napoli

Macedonio G, Pareschi M, Santacroce R (1988) A numerical simulation of the Plinian fall phase of the 79 AD eruption of Vesuvius. J. Geophys. Res 93(B12):14817-14827

Mannella G, Giaccio B, Zanchetta G, Regattieri E, Niespolo EM, Pereira A, Renne PR, Nomade S, Leicher N, Perchiazzi N, Wagner B (2019) Palaeoenvironmental and palaeohydrological variability of mountain areas in the central Mediterranean region: a 190 ka-long chronicle from the independently dated Fucino palaeolake record (central Italy). Quat Sci Rev 210:190-210. https://doi.org/10.1016/j.quascirev.2019.02.032

Marti A, Folch A, Costa A, Engwell S (2016) Reconstructing the plinian and co-ignimbrite sources of large volcanic eruptions: a novel approach for the Campanian Ignimbrite. Sci Rep:111.https://doi.org/10.1038/srep21220

Matthews IP, Trincardi F, Lowe JJ, Bourne AJ, MacLeod A, Abbott PM, Andersen N, Asioli A, Blockley SPE, Lane CS, Oh YA, Satow CS, Staff RA, Wulf S (2015) Developing a robust tephrochronological framework for Late Quaternary marine records in the Southern Adriatic Sea: new data from core station SA03-11. Quat Sci Rev 118:84-104. https://doi.org/10. 1016/j.quascirev.2014.10.009

Mazzella S (1591) Sito e Antichità della città di Pozzuolo ecc., appresso Horatio Salviani, Napoli

Mc Donough CM, Prior RE, Stansbury M (2004) Servius commentary on book four of Virgil's Aeneid - an annotated translation. Bolchazy-Carducci Publishers, Mundelein

Migoń P, Pijet-Migoń E (2019) Natural disasters, geotourism, and geointerpretation. Geoheritage 11:629-640. https://doi.org/10.1007/ s12371-018-0316-X

Morhange C, Bourcier M, Laborel J, Giallanella C, Goiran JP, Crimaco L, Vecchi L (1999) New data on historical relative sea level movements in Pozzuoli, Phlaegrean fields, southern Italy. Phys Chem Earth A 24(4):349-354

Németh K, Casadevall T, Moufti MR, Marti J (2017) Volcanic geoheritage. Geoheritage 9:251-254. https://doi.org/10.1007/ s12371-017-0257-9

Orsi G, D’Antonio M, de Vita S, Gallo G (1992) The Neapolitan Yellow Tuff, a large-magnitude trachytic phreatoplinian eruption: eruptive dynamics, magma withdrawal and caldera collapse. J Volcanol Geotherm Res 53:275-287. https://doi.org/10.1016/ 0377-0273(92)90086-s

Orsi G, de Vita S, Di Vito MA (1996) The restless, resurgent Campi Flegrei nested caldera (Italy): constraints on its evolution and configuration. J Volcanol Geotherm Res 74:179-214

Orsi G, Civetta L, Del Gaudio C, de Vita S, Di Vito MA, Isaia R, Petrazzuoli SM, Ricciardi GP, Ricco C(1999) Short-term ground deformations and seismicity in the resurgent Campi Flegrei caldera (Italy): an example of active block-resurgence in a densely populated area. J Volcanol Geotherm Res (91):415-451

Pacciarelli M, Talamo P (2011) Sull'articolazione dell'età del rame nell'Italia meridionale tirrenica, Atti XLIII Riunione Scientifica - L'età del rame, pp. 87-94

Panarello A, Palombo MR, Biddittu I, Di Vito MA, Farinaro G, Mietto P (2020) On the devil's tracks: unexpected news from the Foresta ichnosite (Roccamonfina volcano, central Italy). J Quat Sci 3/35(2020). https://doi.org/10.1002/jqs.3186

Parascandola A (1947) I fenomeni bradisismici del Serapeo di Pozzuoli. Stabilimento Tipografico Genovese, Napoli
Parascandola A (1946) Il Monte Nuovo e il lago Lucrino. Volume 55; Volumi 1944-1946 di Bollettino della Società dei Naturalisti in Napoli: Società dei Naturalisti. Stab. tip. G. Genovese

Passariello I, Albore LC, Talamo P, Lubritto C, D'Onofrio A, Terrasi F (2009) 14C chronology of Avellino Pumices eruption and timing of human reoccupation of the devasted region. Radiocarbon 51(2009):1-14

Passariello I, Talamo P, D’ Onofrio A, Barta P, Lubritto C, Terrasi F (2010) Contribution of radiocarbon dating to the chronology of Eneolithic in Campania (Italy). Geochronometria 35:25-33

Pereira A, Nomade S, Voinchet P, Bahain JJ, Falguères C, Garon H, Lefèvre D, Raynal JP, Scao V, Piperno M (2015) The earliest securely dated hominin fossil in Italy and evidence of Acheulian occupation during glacial MIS 16 at Notarchirico (Venosa, Basilicata, Italy). J Quat Sci 30:639-650. https://doi.org/10.1002/jqs. 2809

Piperno M, Segre AG (1985) Capri (Campania), in I primi Abitanti d'Europa, Roma, 147-149

Primerano P, Giordano G, Costa A, de Vita S, Di Vito MA (2021) Reconstructing fallout features and dispersal of Cretaio Tephra (Ischia Island, Italy) through field data analysis and numerical modelling: implications for hazard assessment. J Volcanol Geotherm Res. https://doi.org/10.1016/j.jvolgeores.2021.107248

Pyle DM (2000) Sizes of volcanic eruptions. In: Sigurdsson H et al (eds) Encyclopedia of volcanoes. Academic Press, San Diego, pp 263269

Pyle DM, Ricketts GD, Margari V, van Andel TH, Sinitsyn AA, Praslov ND, et al (2006) Wide dispersal and deposition of distal tephra during the Pleistocene "Campanian Ignimbrite/Y5" eruption, Italy. Quat. Sci. Rev 25:2713-2728. https://doi.org/10.1016/j. quascirev.2006.06.008

Ramsey CB, Albert PG, Blockley SPE, Hardiman M, Housley RA, Lane CS, Lee S, Matthews IP, Smith VC, Lowe JJ (2015) Improved age estimates for key Late Quaternary European tephra horizons in the RESET lattice. Quat Sci Rev 118:18-32. https:// doi.org/10.1016/j.quascirev.2014.11.007

Rispoli C, Esposito R, Graziano SF, Di Benedetto C, De Bonis A, Cappelletti P, Talamo P (2017) Antiche malte nella Baia di Napoli: studio della Piscina Mirabile. In: Aveta A, Marino BG, Amore R (eds) La Baia di Napoli - Strategie integrate per la conservazione e la fruizione delpaesaggio culturale vol. 1, Napoli, 2017, 340-344

Rittmann A (1950) Sintesi geologica dei Campi Flegrei. Boll.Soc. Geol. Ital 69:117-128

Rolandi G, Bellucci F, Heizler MT, Belkin HE, Vivo BD (2003) Tectonic controls on the genesis of ignimbrites from the Campanian Volcanic Zone, southern Italy. Mineral Petrol 79:3-31. https:// doi.org/10.1007/s00710-003-0014-4

Rosi M, Sbrana A (1987) The Phlegraean fields. CNR. Quad Ric Sci 114:1-175

Rosi M, Santacroce R (1983) The A.D. 472 "Pollena" eruption: volcanological and petrological data for this poorly-known, Pliniantype event at Vesuvius. J Volcanol Geotherm Res 17:249-271

Rosi M, Vezzoli L, Castelmenzano A, Grieco G (1999) Plinian pumice fall deposit of the Campanian Ignimbrite eruption (Phlegraean Fields, Italy). J Volcanol Geotherm Res 91:179-198. https://doi. org/10.1016/s0377-0273(99)00035-9

Orsi G, Di Vito MA, Isaia R (2004) Volcanic hazard assessment at the restless Campi Flegrei caldera. Bull. Volcanol 66:514-530

Saccoccio F, Marzocchella A, Vanzetti A (2013) The field system of Gricignano d'Aversa (Southern Italy) and the agrarian impact in the Piana Campana, ca. 3900 cal BP. Quat Int 303(2013):82-92

Santacroce R, Cioni R, Marianelli P, Sbrana A, Sulpizio R, Zanchetta G, Donahue DJ, Joron JL (2008) Age and whole rock-glass compositions of proximal pyroclastics from the major explosive eruptions of Somma-Vesuvius: a review as a tool for distal 
tephrostratigraphy. J Volcanol Geotherm Res 177:1-18. https:// doi.org/10.1016/j.jvolgeores.2008.06.009

Scandone R, Bellucci F, Lirer L, Rolandi G (1991) The structure of the Campanian Plain and the activity of the Neapolitan volcanoes (Italy). J Volcanol Geotherm Res 48(1-2):1-31

Scandone R, D'Amato JL, Giacomelli L (2010) The relevance of the 1198 eruption of Solfatara in the Phlegraean Fields (Campi Flegrei) as revealed by medieval manuscripts and historical sources. J Volcanol Geotherm Res 189(1/2):202-206

Scandone R, Giacomelli L (2019) Eruptions, earthquakes and geothermal resources at Campi Flegrei and Ischia. Ann. Geophys 62(1). https://doi.org/10.4401/ag-7661. https://www.annalsofgeophys ics.eu/index.php/annals/article/view/7661

Scandone R, Giacomelli L, Rosi M (2019) Death, Damage and Survival, during the 79 AD Eruption which destroyed Pompeii and Herculaneum, J Reading 2(8):5-30

Scarlett JP, Riede F (2019) The dark geocultural heritage of volcanoes: combining cultural and geoheritage perspectives for mutual benefit. Geoheritage 11:1705-1721. https://doi.org/10.1007/ s12371-019-00381-2

Scarpati C, Cole P, Perrotta A (1993) The Neapolitan Yellow Tuff - a large volume multiphase eruption from Campi Flegrei, Southern Italy. Bull Volcanol 55:343-356. https://doi.org/10.1007/BF003 01145

Sigurdsson H, Cashdollar S, Sparks RSJ (1982) The eruption ofVesuvius in A.D. 79: reconstruction from historical andvolcanological evidence. Am. J. Archaeol 86:39-51

Sigurdsson H, Carey S, Cornell W, Pescatore T (1985) The eruption of Vesuvius in A.D. 79. Natl. Geogr. Res 3:332-397

Silleni A, Giordano G, Isaia R, Ort MH (2020) The magnitude of the 39.8 ka Campanian Ignimbrite eruption, Italy: method, uncertainties and errors. Front Earth Sci 8:L17304-L17322. https:// doi.org/10.3389/feart.2020.543399

Smith VC, Isaia R, Pearce NJG (2011) Tephrostratigraphy and glass compositions of post-15 kyr Campi Flegrei eruptions: implications for eruption history and chronostratigraphic markers. Quat Sci Rev 30:3638-3660. https://doi.org/10.1016/j.quascirev.2011. 07.012

Smith VC, Isaia R, Engwell SL, Albert PG (2016) Tephra dispersal during the Campanian Ignimbrite (Italy) eruption: implications for ultra-distal ash transport during the large calderaforming eruption. Bull Volcanol 78.https://doi.org/10.1007/ s00445-016-1037-0

Sulpizio R, Mele D, Dellino P, La Volpe L (2005) A complex Subplinian-type eruption from low-viscosity, phonolitic to tephriphonolitic magma: the AD 472 (Pollena) eruption of SommaVesuvius, (Italy). Bull Volcanol 67:743-767

Talamo P, De Lorenzo G (2008) Primi dati sul Neolitico Antico della Campania centro-settentrionale, in AttiDaunia XXVIII, 57-70

Talamo P, Ruggini C (2005) Il territorio campano al confine con la Puglia nell'età del Bronzo, in AttiDaunia XXV, pp. 171-188
Talamo P, Passariello I, Lubritto C, Terrasi F (2011) Evoluzione culturale in Campania: indagine cronologica sistematica tramite datazioni radiocarboniche, Atti IIPP XLIII, pp. 39-48

Talamo P (1998) Dinamiche territoriali tra bronzo antico e medio in Irpinia, in Workshop 6 - men and active volcanoes during prehistory and protohistory, Atti del XIII Congresso U.I.S.P.P., Forlì 8-14 settembre 1996, Forlì 1998, vol. VI,1, 329-338

Talamo P (2008a) Dinamiche culturali nelle aree interne della Campania centro-settentrionale durante le prime fasi dell'Eneolitico, Rivista di Scienze Preistoriche LVIII, 125-164

Talamo P (1996) Elementi per una definizione culturale della facies di Palma Campania. In: D.Cocchi Genick (ed.), L'antica età del Bronzo in Italia. Atti del Convegno nazionale Viareggio 9-12 gennaio 1995 (Firenze 1996) 119-134

Talamo P (2008b) Le aree interne della Campania centro-settentrionale durante le fasi evolute dell'Eneolitico: osservazioni sulle dinamiche culturali, Origini XXX (N.S. IV), 187-220

Tamburello G, Caliro S, Chiodini G, De Martino P, Avino R, Minopoli C, Carandente A, Rouwet D, Aiuppa A, Costa A, Bitetto A, Giudice G, Francofonte V, Ricci T, Sciarra A, Bagnato E, Capecchiacci F (2019) Escalating CO2 degassing at the Pisciarelli fumarolic system, and implications for the ongoing Campi Flegrei unrest. J. Volcanol. Geotherm. Res 384:151-157. https:// doi.org/10.1016/j.jvolgeores.2019.07.005

Todesco M, Costa A, Comastri A, Colleoni F, Spada G, Quareni F (2014) Vertical ground displacement at Campi Flegrei (Italy) in the fifth century: Rapid subsidence driven by pore pressure drop, Geophys. Res. Lett., 41, https://doi.org/10.1002/2013GL059083

Tonarini S, D'Antonio M, Di Vito MA, Orsi G, Carandente A (2009) Geochemical and B-Sr-Nd isotopic evidence for mingling and mixing processes in the magmatic system feeding the Astroni volcano (4.1-3.8 ka) within the Campi Flegrei caldera (South Italy). Lithos 107:135-151

Tomlinson EL, Albert PG, Wulf S, Brown RJ, Smith VC, Keller J, Orsi G, Bourne AJ, Menzies MA (2014) Age and geochemistry of tephra layers from Ischia, Italy: constraints from proximaldistal correlations with Lago Grande di Monticchio. J Volcanol Geotherm Res 287:22-39. https://doi.org/10.1016/j.jvolgeores. 2014.09.006

Vezzoli L (1988) Island of Ischia. CNR Quaderni de "La ricerca scientifica”. 114(10):122

Wulf S, Kraml M, Brauer A, Keller J, Negendank JFW (2004) Tephrochronology of the 100ka lacustrine sediment record of Lago Grande di Monticchio (southern Italy). Quat Int 122:7-30. https://doi.org/10.1016/j.quaint.2004.01.028

Zanchetta G, Giaccio B, Bini M, Sarti L (2018) Tephrostratigraphy of Grotta del Cavallo, Southern Italy: insights on the chronology of Middle to Upper Palaeolithic transition in the Mediterranean. Quat Sci Rev 182:65-77. https://doi.org/10.1016/j.quascirev. 2017.12.014 